\title{
Kır teresi (Cardaria draba (L.) Desv.), küçük ısırgan (Urtica urens L.) ve kara banotu (Hyoscyamus niger L.) tohumlarının çimlenme biyolojilerinin araştırılması
}

Investigation of germination biology of some weed seeds such as hoary cress (Cardaria draba (L.) Desv.), annual nettle (Urtica urens L.) and black henbane (Hyoscyamus niger L.)

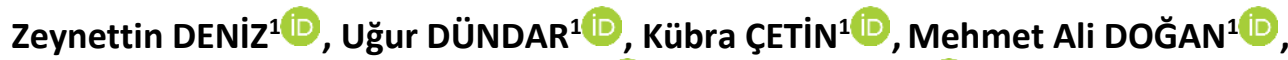 \\ Yücel KARAMAN ${ }^{1}$ iD, Nihat TURSUN ${ }^{1 / D}$ (D) \\ ${ }^{1}$ Malatya Turgut Özal University, Faculty of Agriculture, Department of Plant Protection, Malatya, Turkey.
}

MAKALE BILGISI / ARTICLE INFO

Makale tarihçesi / Article history:

DOI: $10.37908 /$ mkutbd.770318

Geliş tarihi /Received:16.07.2020

Kabul tarihi/Accepted:25.08.2020

\section{Keywords:}

Whitetop (Cardaria draba (L.) Desv), Annual nettle (Urtica urens L.), Black henbane (Hyoscyamus niger L.), dormancy breaking, germination temperature.

\footnotetext{
Corresponding author: Nihat TURSUN

$\bowtie$ : nihat.tursun@ozal.edu.tr
}

\author{
ÖZET / A B STR A C T
}

\begin{abstract}
Aims: The aim of this study is to determine the most appropriate dormancy breaking method and germination temperature in some weed seeds (hoary cress or whitetop (Cardaria draba (L.) Desv.), annual nettle (Urtica urens L.) and black henbane (Hyoscyamus niger L.)).

Methods and Results: The most appropriate germination conditions of whitetop, annual nettle and black henbane weeds were determined by applying different dormancy breaking methods (acid-base (sulfuric acid $(1,2,15,30,60$ and $90 \mathrm{~min})$, hydrochloric acid (5, 15, 30 and $60 \mathrm{~min})$, sodium hydroxide $(50 \%, 40 \%, 30 \%$ and $20 \%$ concentrations $5,10,15$ and $20 \mathrm{~min}$ ) and sodium hypochlorite (5, 10, 15 and $30 \mathrm{~min})$, hormone (gibberellic acid (250, 500, 750 and $1000 \mathrm{ppm})$ ), alcohol (ethanol (5, 15, $30,60,90$ and $120 \mathrm{~min})$ ) and high-low temperature (microwave $(10,30$, 45,90 and $180 \mathrm{sec}$ ), and cold storage ( 0 day control, 1 day $-86^{\circ} \mathrm{C}, 2$ days $86^{\circ} \mathrm{C}$, 4 days $-86^{\circ} \mathrm{C}$ and 7 days $-86^{\circ} \mathrm{C}$ ) and cold soaking + hot water ( 0 days $90^{\circ} \mathrm{C}, 1$ day $-86 / 90^{\circ} \mathrm{C}, 2$ days $-86 / 90^{\circ} \mathrm{C}, 4$ days $-86 / 90^{\circ} \mathrm{C}$ and 7 days $86 / 90^{\circ} \mathrm{C}$ ) and then the most suitable dormancy breaking method and germination temperatures were determined in the seeds of these weeds. Conclusions: According to the results obtained, the most effective dormancy breaking treatments in seeds of whitetop, annual nettle and black henbane were determined as gibberellic acid 500 and 2000 ppm, gibberellic acid $250 \mathrm{ppm}$ and $30 \%$ sodium hydroxide 20 minutes respectively. The most suitable germination rates of weeds were found to be $20^{\circ} \mathrm{C}$ in whitetop and black henbane and $25^{\circ} \mathrm{C}$ in annual nettle.

Significance and Impact of the Study: It is expected that the results obtained will provide an infrastructure for the studies of these weeds in agriculture and non-agriculture.
\end{abstract}

\footnotetext{
Atıf / Citation: Deniz Z, Dündar U, Çetin K, Doğan MA, Karaman Y, Tursun N (2020) Kır teresi (Cardaria draba (L.) Desv.), küçük ısırgan (Urtica urens L.) ve kara banotu (Hyoscyamus niger L.) tohumlarının çimlenme biyolojilerinin araştırılması. MKU. Tar. Bil. Derg. 25(3) : 474-487. DOI: 10.37908/mkutbd.770318
}

\section{Giriş}

Yabancı otlar; kültür bitkilerinin verim ve kalitesini düşüren, kültürel işlemlerin zamanında ve istenilen etkinlikte yapılmasını engelleyen, zehirli tohumlarını ürüne karıştırarak insan ve hayvan sağlığını olumsuz etkileyen, hastalık ve zararlılara konukçuluk yapan bitkilerdir (Anonim, 2019a). Dünyada yabancı otlardan dolayı oluşan ürün kayıpları birçok kültür bitkisinde hastalık ve zararlıların toplamından fazla olmaktadır. 
Gelişmiş ülkelerde yabancı otlar nedeniyle ürünün kalite ve veriminde \%10-15 arasında zarar oluştururken, bazı Asya ülkelerinde bu oran \%45'e ulaşmaktadır. Ülkemizde yetiştirilen farklı kültür bitkilerinde ise bu oran \%2-100 arasında değişmekte ve ortalama \%40-50 oranında zarar yapmaktadır (Gürsoy, 1982; Üremiş ve ark., 2020). Yabancı otlara karşı bir mücadelenin yapılmaması durumunda kültür bitkisinin türüne bağlı olarak \%20-100 ürün kaybı ortaya çıkabilmektedir (Gürsoy, 1982; Yazlık ve Üremiş, 2019; Kaya ve Üremiş, 2020).

Yabancı otların özelliklerinden biri de tohumlarının toprakta uzun süre canlı olarak kalması (dormansi)'dır (Özer ve ark., 1998). Dormansiyi, tohumların iç (tohum kabuğunun su ve gaz geçirmemesi, tohumlarda bulunan kimyasal maddeler) ve dış (sıcaklık, oksijen, ışık) faktörlere bağlı olarak çimlenememesi olayı olarak tanımlayabiliriz (Güncan, 2016). Bir yabancı ot tohumu, olgunluktan çimlenmesine kadar geçen süre zarfı içerisinde zaman zaman durgun dönemlere sahip olabilir. Bu durgunluk dormansi olup bitkinin tür özelliğine göre değişebilir. Dormansi, yabancı otların neslinin devamı ve kendilerini çevreye uyum sağlayabilmeleri açısından son derece önemli olup bir bitkinin yabancı ot olarak önemli özelliklerindendir. Yabancı ot tohumlarının çoğu toprakta çimlenmeden uzun yıllar canlı kalabilirler. Dormansiye sahip olan yabancı ot tohumları toprağa bir kere dökülünce uzun yıllar o toprağın bulaşık kalmasına sebep olurlar (Solak, 2007). Çimlenmenin olabilmesi için dormansinin kırılması gerekmektedir (Obalı, 2009). Çimlenme bitkilerin yaşamında kritik bir aşama olarak bilinmektedir (Keller ve Kollmann, 1999). Yapılan değişik çalışmalarda dormansiye sahip bitkilerde dormansinin kırılmasında ve çimlenmenin arttırılmasında $\mathrm{GA}_{3}$ (giberellik asit) ve IAA (indol asetik asit) gibi bitki büyüme düzenleyicileri (Hilhorst ve Karssen, 1992; Iglesias ve Babiano, 1997), $\mathrm{KNO}_{3}$ ve $\mathrm{H}_{2} \mathrm{SO}_{4}$ gibi kimyasal maddeler (Kevseroğlu, 1993; Hartmann ve ark., 1997; Horowitz ve Taylarson, 1985; Tomer ve Maguire, 1989; Baes ve ark., 2002), sıcak/soğuk uygulamaları (Hermansen ve ark., 1999) vb. önerilmektedir.

Gerek tarım dışı gerekse de tarım alanlarında bulunan kara banotu (Hyoscyamus niger L.), kır teresi (Cardaria draba (L.) Desv.) ve küçük ısırgan otu (Urtica urens L.) bulunduğu alanlarda yabancı ot olarak verdiği zararların yanında tibbi bitki olarak da kullanılmaktadır. Kara banotu bitkisi zehirli yabancı otlar içerinde olmasının yanında tıbbi özelliklerde göstermektedir. Bu bitki dünyanın ılıman bölgelerinde yaygın olarak görülmekte olup bazı bölgelerde hububat tarlalarının önemli yabancı otlarındandır (Özer ve ark., 1999). Kır teresi de yine kışlık hububat, meyve ve sebze alanlarında görülen yabancı otlardan birisi olup bir bitki 5000 civarında tohum oluşturabilmektedir. Küçük ısırgan ise daha çok rutubetli alanları seven bağ, bahçe ve tarla alanlarında görülen yabancı otlar içerinde yer almakta olup (Özer ve ark., 1999) bir bitki 1500 adet tohum üretebilme kapasitesine sahiptir (Coleman ve ark., 2018). Kara banotu gibi tohum kabuğu sert ve geçirimsiz olan yabancı otlarda bulunan dormansi sebebiyle çimlenme oranları doğal olarak çok düşük olmaktadır (Radosevich ve ark., 1997; Çırak ve ark., 2004). Kır teresinin ise 1 yıllık tohumlarında \%84. 2 yıllık tohumlarında \%31 çimlenme görülürken 3 yıllık tohumlarında ise çimlenme olmamaktadır (Bellue, 1946). Küçük ısırgan otunun güçlü bir dormansiye sahip olduğu ve tohumlarının toprakta 10 yıla kadar canlı kalabildiği bildirilmektedir (Coleman ve ark., 2018). Başka bir çalışmada, küçük ısırgan tohumlarının toprakta 20-100 yıl arası canlı kalabildiği bildirilmektedir (Holm ve ark., 1997). Toprağın karıştırılması ile toprağın üst $2.5 \mathrm{~cm}$ 'lik tabakasında çimlenme gösterebilirler. 6 yıl süren ekim hasat işlemlerinden sonra toprak işleme yapılan yerde $\% 4$, yapılmayan yerde ise \%39 tohum canlılığı tespit edilmiştir (Holm ve ark., 1997). Her yabancı otun çimlenme sıcaklıklarında farklı olarak değişiklik göstermektedir. Küçük ısırgan tohumlarının optimum çimlenme sıcaklığı $25^{\circ} \mathrm{C}$ olarak tespit edilmiş ve sıcaklık $20^{\circ} \mathrm{C}^{\prime}$ nin altına düştüğünde çimlenme oranı giderek azalmıştır. Bu yabancı ota ait tohumların ışıklı ortamdan daha çok karanlık ortamlarda iyi çimlenme gösterdiği belirlenmiştir (Andersen, 1968). Kırteresi tohumları ise iki yıl boyunca toprakta canlı olarak kalabilmektedir (Anonim, 2019b). Kara banotu tohumları ise toprakta altı yıl canlı kalırken tipik olarak mera topraklarında 1-5 yıl canlı kalabilmektedir. Ayrıca ekili topraktan elde edilen tohumların beş yıla kadar hayatta kaldıktan sonra filizlendiği bildirilmektedir (CABI, 2019). Bu iki yabancı ot tohumları uzun süre toprakta canlılıklarını devam ettirmemesine rağmen oluşturdukları tohum sayıları ile (Özer ve ark., 1999) yaşantılarını devam ettirebilmektedirler.

Kır teresi, kara banotu ve küçük ısırgan tohumlarının gerek tarım alanlarında gerekse de tarım dışı alanlarda hem mücadelelerinin yapılabilmesi hem de tıbbi açıdan kullanılan bu yabancı otların çimlenme biyolojilerinin iyi bilinmesi gerekmektedir. Bunu sağlayabilmek için ise bu yabancı otların çimlenme sıcaklıkları ve çimlenmenin sağlanabilmesi için dormansilerinin kırılma yöntemlerinin bilinmesi önemli olmaktadır. Her ne kadar kır teresi ve kara banotu tohumları 2-6 yıllık bir süre içerinde toprakta canlılıklarını kaybetseler de oluşturdukları tohum sayıları ile tarım ve tarım dışı 
alanlarda sorun oluşturabilmektedirler. Bu yabancı otlarla ilgili ülkemizde geniş şekilde dormansi kırma ve çimlenme sıcaklığı çalışmaları yapılmamıştır. Bu çalışma bu yabancı otların biyolojilerinin iyi öğrenilebilmesi amacıyla tohumlarına ait en uygun dormansi kırma yönteminin ve en uygun çimlenme sıcaklığını belirlenmesi amacıyla yapılmıştır.

\section{MATERYAL ve YÖNTEM}

Bu çalışma 2019-2020 yıllarında Malatya Turgut Özal Üniversitesi Ziraat Fakültesine ait herboloji laboratuvarında iklim kabini, etüv, buzdolabı ve inkübatör gibi materyaller kullanılarak yürütülmüştür. Çalışmada ana materyal olarak 2-3 yıllık yabancı ot tohumları kullanılmıştır. Bu tohumlardan kır teresi ve kara banotu tohumları toprakta kısa süre içerisinde canlııklarını kaybettikleri için $(2-5$ yıl), tohumlar araziden toplandıktan sonra hemen $+4{ }^{\circ} \mathrm{C}$ sıcaklıkta buzdolabında muhafaza edilmiştir. $\mathrm{Bu}$ şekilde tohumların canlılıklarının daha uzun süre devam etmesi sağlanmıştır.

Denemede kır teresi (Cardaria draba (L.) Desv), küçük Isırgan (Urtica urens L.) ve kara banotu (Hyoscyamus niger L.) yabancı ot tohumlarının dormansi kırma yöntemlerinin ve çimlenme sıcaklığının belirlenmesi çalışmaları yürütülmüştür.

\section{Dormansi Kırma Çalışmaları}

Kırteresi, küçük ısırgan, kara banotu tohumlarının çimlenme sıcaklığının ve dormansiye sahip olan bu yabancı ot tohumlarında en uygun dormansi yönteminin belirlenebilmesi için farklı dormansi kırma uygulamaları gerçekleştirilmiştir. Çalışmalar 4 tekerrürlü ve 2 tekrarlı olarak yürütülmüştür. Dormansi kırma işlemlerinden önce tohumlar kullanılıncaya kadar $+4^{\circ} \mathrm{C}^{\prime}$ de muhafaza edilmiştir. Çalışmada kullanılan tohumlar, yüzey sterilizasyonu için $\% 1^{\prime} l i k$ sodyum hipoklorit çözeltisinde 1 dakika bekletildikten sonra saf su ile yıkanmış ve kurutulmuştur. Çalışmada $9 \mathrm{~cm}$ çapındaki steril plastik petri kaplarının tabanına çift kat Whatman No:1 filtre kağıdı yerleştirilerek dormansi kırma uygulamalarından sonra $3 \mathrm{~mL}$ saf su eklenen petriler iklim kabinine alınmıştır. Kontrolde sadece saf su, giberellik asit uygulamasında ise hazırlanan solüsyonlar kullanılmıştır. Her petri kabının içerisine 10 adet tohum konulmuştur. Tüm çalışma $20^{\circ} \mathrm{C}$ sabit sıcaklıktaki iklim kabininde karanlık ortamda gerçekleştirilmiştir. Denemede çimlenme oranlarının ve sürelerinin belirlenebilmesi için sayımlar her gün olmak koşulu ile toplamda 14 gün sayılmış ve radikulası (kökçük) $0.5 \mathrm{~cm}$ 'den büyük olan tohumlar çimlenmiş olarak kabul edilmiş ve çimlenen tohumlar petri kabının dışına alınmıştır. Deneme boyunca intiyaç duyulduğunda saf su ilave edilmiştir.

Denemede kullanılan tohumlara dormansi kırma çalışmalarında asit-baz (sülfürik asit $(1,2,15,30,60$ ve $90 \mathrm{dk})$, hidroklorik asit $(5,15,30$ ve $60 \mathrm{dk})$, sodyum hidroksit (\%50, \%40, \%30 ve \%20 konsantrasyonlarda 5, $10,15$ ve $20 \mathrm{dk})$ ve sodyum hipoklorit $(5,10,15$ ve 30 dk)), hormon (giberellik asit $(250,500,750$ ve 1000 ppm)), alkol (etanol $(5,15,30,60,90$ ve $120 \mathrm{dk}))$ ve yüksek-düşük sıcaklık (mikrodalga $(10,30,45,90$ ve 180 $\mathrm{sn}$ ), ve soğukta bekletme (0 gün kontrol, 1 gün $-86^{\circ} \mathrm{C}, 2$ gün $-86^{\circ} \mathrm{C}, 4$ gün $-86^{\circ} \mathrm{C}$ ve 7 gün $\left.-86^{\circ} \mathrm{C}\right)$ ve soğukta bekletme + sıcak su ( 0 gün $90^{\circ} \mathrm{C}, 1$ gün $-86 / 90^{\circ} \mathrm{C}$, 2 gün $86 / 90^{\circ} \mathrm{C}$, 4 gün $-86 / 90^{\circ} \mathrm{C}$ ve 7 gün $\left.-86 / 90^{\circ} \mathrm{C}\right)$ ) uygulamaları yapılmıştır. Yapılan çalışmalarda çimlenme sayımları her gün olmak koşulu ile yapılarak çimlenme oranları ve süreleri tespit edilmiştir.

Sayımlar tamamlandıktan sonra çimlenme oranı (Gmax) ve süreleri $\left(T_{50}\right.$ ve $\left.T_{90}\right)$ değerleri hesaplanmıştır. Buna göre:

$G_{\max }=\frac{G}{T} \times 100$

G: Çimlenen tohum sayısı (adet/petri), $\mathrm{T}$ : Kullanılan toplam tohum sayısı (adet/petri).

$\mathrm{T}_{50}=$ Çimlenen tohumların \%50'sinin çimlenmesi için geçen süre (gün).

$\mathrm{T}_{90}=$ Çimlenen tohumların $\% 90$ 'ının çimlenmesi için geçen süre (gün).

Çalışmadaki dormansi kırma çalışmalarında uygulanan; asit-baz (sülfürik asit, hidroklorik asit, sodyum hidroksit ve sodyum hipoklorit), hormon (giberellik asit), alkol (etanol) ve yüksek/düşük sıcaklık (mikrodalga, soğukta bekletme ve soğukta bekletme + sicak su) uygulamalarına bilgiler aşağıda verilmiştir.

\section{Sülfürik asit uygulaması}

Kır teresi, küçük ısırgan ve kara banotu tohumları \%97'lik sülfürik asitte $\left(\mathrm{H}_{2} \mathrm{SO}_{4}\right) 1,2,5,15,30,60$ ve 90 dakika bekletilmiştir (Majd ve ark., 2013; Ateş, 2017).

\section{Hidroklorik asit uygulaması}

Denemede kullanılan tohumlar \% 32'lik hidroklorik asitte $(\mathrm{HCl})$ 1, 2, 5, 15, 30, 60 ve 90 dakika bekletilmiştir

\section{Sodyum hidroksit uygulaması}

Kır teresi, küçük ısırgan ve kara banotu tohumları sodyum hidroksitin $(\mathrm{NaOH}) \% 50, \% 40, \% 30$ ve \%20 
konsantrasyonlarda 5, 10, 15 ve 20 dakika bekletilmiştir (Majd ve ark., 2013; Ateş, 2017).

\section{Sodyum hipoklorit uygulaması}

Kır teresi, küçük ısırgan ve kara banotu tohumları \%15'lik sodyum hipoklorit çözeltisinde ( $\mathrm{NaClO}) 5,10$, 15, 30 dakika bekletilmiştir (Ateş, 2017).

\section{Gibberellik asit uygulaması}

Çalışmada kır teresi, küçük ısırgan ve kara banotu tohumları bulunan petri kaplarının içerisine gibberellik asidin $\left(\mathrm{GA}_{3}\right)$ farklı konsantrasyonlarında $(250,500,1000$ ve $2000 \mathrm{ppm}$ ) hazırlanan solüsyonları $3 \mathrm{~mL}$ ilave edilerek $20^{\circ} \mathrm{C}$ sabit sıcaklıktaki iklim kabinine yerleştirilmiştir (Ateş, 2017).

\section{Etanol uygulaması}

Yabancı ot tohumları \% 96'lık etanolde 5, 15, 30, 60, 90 ve 120 dakika eppendorf tüplerinde bekletilmiştir.

\section{Mikrodalga uygulaması}

Bu yöntemde tohum embriyosunu tahrip etmeksizin tohumun içerdiği suyun hareket kazanarak embriyonun uyarılması amaçlanmıştır. Bu yöntemle kır teresi, küçük ısırgan ve kara banotu tohumlarından her biri cam petri kaplarına 40'ar adet konularak 10, 30, 60, 90, 120 ve 180 saniye 100 watt mikrodalga ışınlarına maruz bırakılmıştır (Ateş, 2017).

\section{Soğukta bekletme uygulaması}

Tohumlar farklı sürelerde $\left(0,1,2,4\right.$ ve 7 gün) $-86^{\circ} \mathrm{C}^{\prime}$ de bekletilip petrilere aktarılmış ve $3 \mathrm{~mL}$ saf su uygulanmıştır. Çalışmada sayımlar her gün olacak şekilde 7 gün sürmüştür (Tiryaki ve Topu, 2014).

\section{Soğukta bekletme + sıcak su uygulaması}

Tohumlar farklı sürelerde $\left(0,1,2,4\right.$ ve 7 gün) $-86^{\circ} \mathrm{C}^{\prime}$ de bekletildikten sonra $90^{\circ} \mathrm{C}$ suda 5 saniye bekletilip petrilere aktarılmıs ve $3 \mathrm{~mL}$ saf su uygulanmıştır. Bu uygulamada da sayımlar her gün olacak şekilde 7 gün sürmüştür (Tiryaki ve Topu, 2014).

\section{Çimlenme Sıcaklığı Çalışmaları}

Çimlenme sıcaklığı çalışmaları karanlık ortamda 4 tekerrürlü olarak yürütülmüştür. Çalışmada kırteresi, küçük ısırgan ve kara banotu tohumlarının yüzey sterilizasyonu yapıldıktan sonra (\%1'lik $\mathrm{NaClO}$ ) tohumların dormansisini kırmak için $20^{\circ} \mathrm{C}$ 'de en uygun dormansi yöntemleri uygulanmıştır. Çimlenme sıcaklığı çalışmaları kır teresi, küçük ısırgan ve kara banotu tohumlarına sırasıyla giberellik asit 500 ile 2000 ppm, giberellik asit $250 \mathrm{ppm}$ ve $\% 30$ sodyum hidroksit $20 \mathrm{dk}$ olan en uygun dormansi yöntemi belirlendikten sonra kurulmuştur. Dormansi uygulaması yapıldıktan sonra 9 $\mathrm{cm}$ çapındaki çift filtre kağıdı yerleştirilen steril petri kaplarına 10 adet tohum konulduktan sonra üzerine 3 $\mathrm{mL}$ saf su eklenmiş ve $5,10,15,20,25,30,35,40$ ve $45^{\circ} \mathrm{C}$ sıcaklıklara ayarlanmış çimlenme kabinlerine, karanlık ortamlara bırakılmıştır. Çimlenme oranlarını ve sürelerini belirlemek amacıyla sayımlar her gün olacak şekilde 21 gün devam etmiş ve $0.5 \mathrm{~cm}$ çim borucuğu (radikula) oluşturan tohumlar çimlenmiş olarak kabul edilmiştir.

\section{İstatistiki Analizler}

Dormansi kırma çalışması her uygulama için 4 tekerrürlü ve 2 tekrarlamalı olarak olarak kurulmuştur. 1. ve 2. uygulamalar arasında istatistiki olarak fark çıkmadığı için iki denemenin ortalaması alınarak değerlendirmeler yapılmıştır. Tohumların çimlenme sayıları sabit olmaya başladığı süre olan 14 gün boyunca sayımlar günlük yapılmış ve $0.5 \mathrm{~cm}$ çim borucuğu oluşturmuş tohumlar çimlenmiş olarak kabul edilmiştir. Çimlenme oranlarını ve sürelerinin belirlenmesi çalışmasında ise sayımlar günlük olarak 21 gün devam etmiştir. Verilerin değerlendirilmesinde GLM model tek yönlü varyans analizi (ANOVA) uygulanmıştır. Uygulamalar arasındaki fark Duncan çoklu karşılaştırma testi $(P \quad$ S0.05) kullanılarak bulunmuştur. Tüm hesaplamalarda IBM SPSS 25 istatistik paket programı kullanılmıştır

\section{BULGULAR ve TARTIŞMA}

Kır teresi (Cardaria draba (L.) Desv), küçük ısırgan (Urtica urens L.) ve kara banotu (Hyoscyamus niger L.) tohumlarında dormansinin olduğu bilinmektedir (Bellue, 1946; Radosevich ve ark., 1997; Coleman ve ark., 2018). Bu yabancı ot tohumlarında dormansi bulunması toprakta uzun yıllar canlı kalabilme nedenleri arasında yer almaktadır (Solak, 2007). Toprakta uzun yıllar boyunca dormant halde kalan tohumların kültür arazilerinde problem teşkil edeceği öngörülmekte ve yabancı otların mücadelesine yönelik uygulamalarda doğru yöntemlerin uygulanması için yabancı otların dormansi, üreme yetenekleri ve çimlenme sıcaklıkları gibi biyolojik özelliklerini bilinmesi oldukça önemli olmaktadır (Ateş, 2017). Araştırmacıların bu yabancı ot tohumlarının dormansi kırma durumu ve çimlenme sıcaklığı gibi çimlenme biyolojilerini iyi bilmeleri önem teşkil etmektedir.

\section{Dormansi Kırma Çalışmaları}

Yapılan çalışmalarda kara banotu tohumlarında sadece farklı (\%) sodyum hidroksite sahip kimyasal 
uygulamasında çimlenme gerçekleşmiştir, ancak diğer uygulamalarda herhangi bir çimlenme olmadığı için sonuçlar ayrıca verilmemiştir. Çırak ve ark. (2004) yılında yaptıkları çalışmalarda da çimlenme oranları yaptığımız çalışmada olduğu gibi karanlık ortamda oldukça düşük çıkmış aydınlık ortamlarda ise nispet çimlenme oranlarının daha yüksek olduğu belirlenmiştir. $\mathrm{Bu}$ durum kara banotu tohum çimlenmesi için aydınlık ortamın daha uygun olduğu sonucunu ortaya çıarabilmektedir.

Çizelge 1. Kır teresi (Cardaria draba (L.) Desv.) tohumlarının çimlenme oranları (\%) ve sürelerine asit-baz uygulamalarının etkisi

Table 1. The effect of acid-base applications on the germination rates and durations of whitetop (Cardaria draba (L.) Desv.) seeds

\begin{tabular}{|c|c|c|c|c|}
\hline & & Gmax (\%) & $T_{50}$ (gün) & $T_{90}$ (gün) \\
\hline Kontrol & & $42.5 \pm 4.79 d$ & $6 \pm 0.41 \mathrm{ab}$ & $11 \pm 0.71 a$ \\
\hline \multirow{7}{*}{ Sülfürik asit (\%97) } & $1 \mathrm{dk}$ & $65 \pm 5.41 b c$ & $6 \pm 0.71 a b$ & $9.25 \pm 0.63 a b c$ \\
\hline & $2 \mathrm{dk}$ & $56.25 \pm 3.75 \mathrm{~cd}$ & $6 \pm 0.41 \mathrm{ab}$ & $10.25 \pm 0.63 a b$ \\
\hline & $5 \mathrm{dk}$ & $81.25 \pm 7.74 a b$ & $4 \pm 0 b c d$ & $6.5 \pm 0.87 b c$ \\
\hline & $15 \mathrm{dk}$ & $77.5 \pm 3.23 a b c$ & $3.5 \pm 0.29 c d$ & $8.5 \pm 1.05 a b c$ \\
\hline & $30 \mathrm{dk}$ & $76.25 \pm 1.25 a b c$ & $4.25 \pm 0.95 b c d$ & $8.25 \pm 1.71 \mathrm{abc}$ \\
\hline & $60 \mathrm{dk}$ & $51.25 \pm 11.97 c d$ & $5.25 \pm 0.95 b c$ & $8.5 \pm 1.9 a b c$ \\
\hline & $90 \mathrm{dk}$ & $0 \pm 0 d$ & $0 \pm 0 d$ & $0 \pm 0 d$ \\
\hline \multirow{7}{*}{ Hidroklorik asit (\%33) } & $1 \mathrm{dk}$ & $75 \pm 3.54 a b c$ & $5 \pm 0 \mathrm{bcd}$ & $7.5 \pm 0.96 a b c$ \\
\hline & $2 \mathrm{dk}$ & $73.75 \pm 8.01 \mathrm{abc}$ & $5 \pm 0 \mathrm{bcd}$ & $7.75 \pm 1.44 a b c$ \\
\hline & $5 \mathrm{dk}$ & $85 \pm 5.41 \mathrm{ab}$ & $4.75 \pm 0.25 b c d$ & $6 \pm 0 \mathrm{~cd}$ \\
\hline & $15 \mathrm{dk}$ & $96.25 \pm 2.4 a$ & $3.75 \pm 0.25 b c d$ & $4.75 \pm 0.48 c d$ \\
\hline & $30 \mathrm{dk}$ & $90 \pm 4.57 a$ & $3 \pm 0 \mathrm{~cd}$ & $5 \pm 0.71 c d$ \\
\hline & $60 \mathrm{dk}$ & $2.5 \pm 2.5 d$ & $2.75 \pm 2.75 d$ & $2.75 \pm 2.75 d$ \\
\hline & $90 \mathrm{dk}$ & $0 \pm 0 d$ & $0 \pm 0 d$ & $0 \pm 0 \mathrm{~d}$ \\
\hline \multirow{4}{*}{ Sodyum hidroksit (\%50) } & $5 \mathrm{dk}$ & $90 \pm 3.54 a$ & $4.75 \pm 0.25 b c d$ & $6 \pm 0.41 c d$ \\
\hline & $10 \mathrm{dk}$ & $88.75 \pm 2.4 a$ & $3.75 \pm 0.25 b c d$ & $5.25 \pm 0.25 c d$ \\
\hline & $15 \mathrm{dk}$ & $93.75 \pm 2.4 a$ & $4.5 \pm 0.29 b c d$ & $7 \pm 1.36 \mathrm{bc}$ \\
\hline & $20 \mathrm{dk}$ & $90 \pm 5.41 a$ & $4 \pm 0 \mathrm{bcd}$ & $6.25 \pm 0.63 \mathrm{~cd}$ \\
\hline \multirow{4}{*}{ Sodyum hidroksit (\%40) } & $5 \mathrm{dk}$ & $81.25 \pm 4.27 a b$ & $4 \pm 0 \mathrm{bcd}$ & $6.25 \pm 0.48 c d$ \\
\hline & $10 \mathrm{dk}$ & $68.75 \pm 8.75 b c$ & $3.75 \pm 0.25 b c d$ & $8 \pm 1.59 \mathrm{abc}$ \\
\hline & $15 \mathrm{dk}$ & $66.25 \pm 2.4 b c$ & $5.5 \pm 0.29 b c$ & $7.25 \pm 0.48 b c$ \\
\hline & $20 \mathrm{dk}$ & $78.75 \pm 1.25 a b$ & $4.25 \pm 0.25 b c d$ & $6.75 \pm 0.25 b c$ \\
\hline \multirow{4}{*}{ Sodyum hidroksit (\%30) } & $5 \mathrm{dk}$ & $80 \pm 10.61 a b$ & $3.5 \pm 0.29 \mathrm{~cd}$ & $5.25 \pm 0.25 \mathrm{~cd}$ \\
\hline & $10 \mathrm{dk}$ & $88.75 \pm 1.25 a$ & $4.5 \pm 0.29 b c d$ & $8.25 \pm 0.95 a b c$ \\
\hline & $15 \mathrm{dk}$ & $66.25 \pm 10.29 b c$ & $6.75 \pm 1.11 \mathrm{ab}$ & $10.5 \pm 1.33 a b$ \\
\hline & $20 \mathrm{dk}$ & $37.5 \pm 11.64 d$ & $5 \pm 1.69 \mathrm{bcd}$ & $7 \pm 2.39 \mathrm{bc}$ \\
\hline \multirow{4}{*}{ Sodyum hidroksit (\%20) } & $5 \mathrm{dk}$ & $81.25 \pm 5.55 a b$ & $4.25 \pm 0.25 b c d$ & $8.25 \pm 1.98 a b c$ \\
\hline & $10 \mathrm{dk}$ & $46.25 \pm 6.58 d$ & $8 \pm 0.71 a$ & $12.5 \pm 0.96 a$ \\
\hline & $15 \mathrm{dk}$ & $1.25 \pm 1.25 \mathrm{~d}$ & $0 \pm 0 d$ & $0 \pm 0 d$ \\
\hline & $20 \mathrm{dk}$ & $0 \pm 0 d$ & $0 \pm 0 d$ & $0 \pm 0 d$ \\
\hline \multirow{4}{*}{ Sodyum hipoklorit (\%15) } & $5 \mathrm{dk}$ & $56.25 \pm 6.25 \mathrm{~cd}$ & $5.75 \pm 0.25 b c$ & $7.25 \pm 0.75 b c$ \\
\hline & $10 \mathrm{dk}$ & $60 \pm 4.57 \mathrm{bcd}$ & $5.25 \pm 0.25 b c$ & $6.5 \pm 0.5 b c$ \\
\hline & $15 \mathrm{dk}$ & $58.75 \pm 7.47 \mathrm{~cd}$ & $5 \pm 0 \mathrm{bcd}$ & $6.5 \pm 0.5 b c$ \\
\hline & $30 \mathrm{dk}$ & $73.75 \pm 4.27 a b c$ & $4,25 \pm 0.25 b c d$ & $6.75 \pm 1.44 b c$ \\
\hline $\mathbf{F}$ & & $26.54 * *$ & $7.57 * *$ & $7.48 * *$ \\
\hline
\end{tabular}

$\pm=$ Standart sapma değerlerini vermektedir. $+* *$ Duncan $P<0.01$ önem seviyesinde istatistiksel olarak önemlidir

Kırteresi tohumlarına yönelik dormansi kırma çalışmalarında tohumları sülfürik ve hidroklorik asitte bekletmenin çok iyi sonuç verdiği fakat belirli bir süreden sonra (60 ve $90 \mathrm{dk}$ ) tohuma zarar verdiği gözlenmiş bunun sonucunda da çimlenmelerde azalma görülmüş veya tamamen durmuştur. Aynı tohumda sodyum hidroksit ( $\mathrm{NaOH})$ uygulamalarında ise en yüksek çimlenmelerin görüldüğü $\% 50 \mathrm{NaOH}$ uygulaması 
olmuştur. Diğer $\mathrm{NaOH}$ uygulamalarının da iyi sonuç verdiği fakat \%30 NaOH $20 \mathrm{dk}, \% 20 \mathrm{NaOH} 15$ ve $20 \mathrm{dk}$ uygulamalarının çimlenmeyi azalttığı gözlenmiştir. Sodyum hipoklorit uygulamasında sürelerin arttırılması kır teresi tohumlarının çimlenmesini arttırmıştır (Çizelge 1). Giberellik asit uygulaması dormansi kırmada tohumlara uygulanabilecek en iyi yöntem olarak belirlenmiştir (Çizelge 2). Alkol uygulamasının kır teresi tohumlarında az da olsa çimlenmeyi teşvik ettiği gözlenmiştir (Çizelge 3). Yüksek-düşük sıcaklık uygulamalarında mikrodalga ve soğukta bekletme uygulamasının çimlenmeyi arttırdığı fakat soğukta bekletme + sıcak su uygulamasının çimlenmeyi azalttığı veya tamamen durdurduğu gözlenmiştir. Sıcak su uygulamasında yüksek derecedeki suyun tohuma zarar verdiği ve bu sebeple çimlenmelerde negatif bir etkinin meydana geldiği söylenebilir. Ayrıca mikrodalga uygulamalarında tohum çimlenmesinde dalgalanmalar meydana gelmesine rağmen istatistiksel açıdan uygulamalar aynı grup içerinde yer almıştır (Çizelge 4). Cardaria draba ile aynı familyada olan Myagrum perfoliatum üzerine yapılan dormansi kırma çalışmalarında Bozdoğan ve ark. (2019), tohumlara bazı kimyasallar (sodyum hipoklorit, etanol, saf su, sülfürik asit ve hidroklorik asit), hormonlar (giberellik asit) ve yüksek/düşük sıcaklıklar [(mikrodalga $(120 \mathrm{~W}),-80^{\circ} \mathrm{C}$, $80^{\circ} \mathrm{C}$ ve $+80^{\circ} \mathrm{C}$ (bir dakika bekletme)] uygulamışlardır. Myagrum perfoliatum üzerine yapılan bu çalışmada en iyi çimlenme sonuçları etanol ve hidroklorik asit uygulamalarında gözlenmiştir. Çalışmadaki hidroklorik asit uygulaması çalışmamıza paralel sonuçlar göstermiştir. Benzer bir çalışma olarak Ateş (2017), yine aynı familyada (Brassicaceae) olan Sinapis arvensis üzerine yaptığı dormansi kırma çalışmasında en iyi sonucu giberellik asit uygulamasında almış ve hidroklorik asit uygulamasının çimlenme üzerinde pozitif bir etkiye sahip olduğunu belirlemiştir. Yapılan bu çalışmalar doğrultusunda $C$. draba gibi Brassicaceae familyasına ait tohumlardaki dormansi kırma yöntemlerinde giberellik ve hidroklorik asit gibi uygulamaların iyi sonuç verdiği görülmektedir. Kır teresinin çimlenme sürelerine $\left(T_{50}\right.$ ve $\left.T_{90}\right)$ bakıldığında çimlenen tohumların $\% 50$ 'sinin çimlenme süreleri ortalama 3 ile 5 gün arasında ve \%90'ının ise 6 ile 10 gün arasında çimlendiği gözlenmiştir. En etkili dormansi kırma uygulaması olan giberellik asit 500 ile 2000 ppm'de çimlenen tohumların $\% 50$ 'sinin ve $\% 90$ 'ının çimlenme sürelerinin 5 ile 7 gün arasında olduğu belirlenmiştir.

Çizelge 2. Kır teresi (Cardaria draba (L.) Desv.) tohumlarının çimlenme oranları (\%) ve sürelerine giberallik asit uygulamalarının etkisi

Table 2. The effect of gibberallic acid applications on the germination rates and durations of whitetop (Cardaria draba (L.) Desv.) seeds.

\begin{tabular}{|c|c|c|c|c|}
\hline & & Gmax (\%) & $T_{50}$ (gün) & T90 (gün) \\
\hline & Kontrol & $42.5 \pm 4.79 b$ & $6 \pm 0.41 \mathrm{ab}$ & $11 \pm 0.71 a$ \\
\hline \multirow{4}{*}{ Giberellik asit } & 250 ppm & $95 \pm 2.89 a$ & $6.25 \pm 0.48 a$ & $10.25 \pm 0.86 a$ \\
\hline & 500 ppm & $98.75 \pm 1.25 a$ & $5.25 \pm 0.48 a b c$ & $8.25 \pm 0.48 b$ \\
\hline & 1000 ppm & $97.5 \pm 2.5 a$ & $4.75 \pm 0.25 c$ & $6 \pm 0.41 c$ \\
\hline & 2000 ppm & $98.75 \pm 1.25 a$ & $5 \pm 0 \mathrm{bc}$ & $6.5 \pm 0.5 b c$ \\
\hline \multicolumn{2}{|r|}{$\mathbf{F}$} & $74.75 * *$ & $3.05 *$ & $13.05^{* *}$ \\
\hline
\end{tabular}

$\pm=$ Standart sapma değerlerini vermektedir. $+^{*}=$ Duncan $P<0.05$ önem seviyesinde istatistiksel olarak önemlidir. $+* *=$ Duncan $P<0.01$ önem seviyesinde istatistiksel olarak önemlidir.

Çizelge 3. Kır teresi (Cardaria draba (L.) Desv.) tohumlarının çimlenme oranları (\%) ve sürelerine etanol uygulamalarının etkisi Table 3. The effect of ethanol applications on the germination rates and durations of whitetop (Cardaria draba (L.) Desv.) seeds.

\begin{tabular}{|c|c|c|c|c|}
\hline & & Gmax (\%) & $T_{50}$ (gün) & $T_{90}$ (gün) \\
\hline \multicolumn{2}{|c|}{ Kontrol } & $42.5 \pm 4.79 a b$ & $6 \pm 0.41 a b$ & $11 \pm 0.71 a$ \\
\hline \multirow{6}{*}{ Etanol (\%96) } & $5 \mathrm{dk}$ & $60 \pm 3.54 a$ & $5.5 \pm 0.29 a b$ & $8 \pm 0.71 a b c$ \\
\hline & $15 \mathrm{dk}$ & $51.25 \pm 9.66 a b$ & $5 \pm 0.41 a b$ & $7 \pm 0.82 c$ \\
\hline & $30 \mathrm{dk}$ & $41.25 \pm 4.27 \mathrm{~b}$ & $6.5 \pm 1.2 \mathrm{a}$ & $10.75 \pm 1.61 \mathrm{ab}$ \\
\hline & $60 \mathrm{dk}$ & $51.25 \pm 6.58 a b$ & $5.5 \pm 0.29 a b$ & $7 \pm 0.41 c$ \\
\hline & $90 \mathrm{dk}$ & $52.5 \pm 4.79 a b$ & $4.5 \pm 0.29 b$ & $7.75 \pm 1.25 b c$ \\
\hline & $120 \mathrm{dk}$ & $60 \pm 2.05 a$ & $5.75 \pm 0.48 \mathrm{ab}$ & $8 \pm 0.58 \mathrm{abc}$ \\
\hline \multicolumn{2}{|c|}{$\mathbf{F}$} & 1.78öd & $1.340 ̈ d$ & $3.13 *$ \\
\hline
\end{tabular}

$\pm=$ Standart sapma değerlerini vermektedir. + öd $=$ İstatiksel olarak önemli değildir. (Duncan $P>0.05)+*=$ Duncan $P<0.05$ önem seviyesinde istatistiksel olarak önemlidir. 
Çizelge 4. Kır teresi (Cardaria draba (L.) Desv.) tohumlarının çimlenme oranları (\%) ve sürelerine yüksek-düşük sıcaklık uygulamalarının etkisi

Table 4. The effect of high-low temperature applications on the germination rates and durations of whitetop (Cardaria draba (L.) Desv.) seeds.

\begin{tabular}{|c|c|c|c|c|}
\hline & & Gmax (\%) & $T_{50}$ (gün) & $T_{90}$ (gün) \\
\hline Kontrol & & $42.5 \pm 4.79 \mathrm{c}$ & $6 \pm 0.41 a$ & $11 \pm 0.71 \mathrm{ab}$ \\
\hline \multirow{6}{*}{ Mikrodalga (100 watt) } & $10 \mathrm{~s}$ & $63.75 \pm 2.4 \mathrm{ab}$ & $5 \pm 0 a$ & $8 \pm 1.69 a b$ \\
\hline & $30 \mathrm{~s}$ & $66.25 \pm 6.58 \mathrm{ab}$ & $5 \pm 0 a$ & $6 \pm 0 b$ \\
\hline & $60 \mathrm{~s}$ & $63.75 \pm 9.66 a b$ & $4.75 \pm 0.25 a$ & $6 \pm 0 b$ \\
\hline & $90 \mathrm{~s}$ & $57.5 \pm 8.54 a b c$ & $5.25 \pm 0.25 a$ & $6.25 \pm 0.48 b$ \\
\hline & $120 \mathrm{~s}$ & $53.75 \pm 8.27 \mathrm{bc}$ & $4.75 \pm 0.25 a$ & $7 \pm 0.41 \mathrm{ab}$ \\
\hline & $180 \mathrm{~s}$ & $66.25 \pm 2.4 \mathrm{ab}$ & $6 \pm 0.41 a$ & $9.5 \pm 0.96 \mathrm{ab}$ \\
\hline \multirow{4}{*}{ Soğukta bekletme } & 1 gün $-86^{\circ} \mathrm{C}$ & $42.5 \pm 6.62 c$ & $5.25 \pm 0.48 a$ & $8.5 \pm 1.56 a b$ \\
\hline & 2 gün $-86^{\circ} \mathrm{C}$ & $50 b \pm 9.36 c$ & $5.5 \pm 0.65 a$ & $12.25 \pm 0.63 a$ \\
\hline & 4 gün $-86^{\circ} \mathrm{C}$ & $73.75 \pm 5.55 a$ & $5.75 \pm 0.25 a$ & $9.5 \pm 0.96 a b$ \\
\hline & 7 gün $-86^{\circ} \mathrm{C}$ & $63.75 \pm 6.89 \mathrm{ab}$ & $6.5 \pm 0.29 a$ & $8.5 \pm 0.65 a b$ \\
\hline \multirow{5}{*}{ Soğukta bekletme + Sıcak su } & 0 gün $90^{\circ} \mathrm{C}$ & $0 \pm 0 d$ & $0 \pm 0 \mathrm{~b}$ & $0 \pm 0 c$ \\
\hline & 1 gün $-86 / 90^{\circ} \mathrm{C}$ & $0 \pm 0 d$ & $0 \pm 0 b$ & $0 \pm 0 c$ \\
\hline & 2 gün $-86 / 90^{\circ} \mathrm{C}$ & $6.25 \pm 3.75 d$ & $6.75 \pm 3.91 a$ & $6.75 \pm 3.91 b$ \\
\hline & 4 gün $-86 / 90^{\circ} \mathrm{C}$ & $11.25 \pm 6.58 \mathrm{~d}$ & $5.25 \pm 3.04 a$ & $7 \pm 4.05 \mathrm{ab}$ \\
\hline & 7 gün $-86 / 90^{\circ} \mathrm{C}$ & $0 \pm 0 \mathrm{~d}$ & $0 \pm 0 \mathrm{~b}$ & $0 \pm 0 c$ \\
\hline $\mathbf{F}$ & & $21.3 * *$ & $3.28^{* *}$ & $5.53 * *$ \\
\hline
\end{tabular}

$\pm=$ Standart sapma değerlerini vermektedir. $+^{* *}=$ Duncan $P<0.01$ önem seviyesinde istatistiksel olarak önemlidir

Küçük ısırgan tohumlarına yönelik dormansi çalışmalarında tohumları sülfürik ve hidroklorik asitte sadece 120 sn bekletmenin çimlenmeyi çok az da olsa arttırdığı gözlenmiştir (Çizelge 5). Sülfürik ve hidroklorik asitin diğer uygulamaları çimlenmeyi azaltmış veya tamamen durdurmuştur. Asit uygulamasının küçük ısırgan tohumlarının çimlenmesini azaltma nedeni olarak tohum embriyosunda zararların meydana geldiği düşünülmektedir. Tohumların sodyum hidroksitin $(\mathrm{NaOH})$ içerinde \%40'lık uygulamasında $15 \mathrm{dk}$, \%30'luk uygulamasında 10,15 ve $20 \mathrm{dk}$ ve $\% 20^{\prime}$ lik uygulamasında $20 \mathrm{dk}$ bekletilmeleri hariç diğer uygulamalar çimlenmeyi teşvik etmiştir. Sodyum hipoklorit uygulaması içerinde tohumların bekletilme süreleri arttıkça küçük ısırgan tohumlarının çimlenmelerini arttığı belirlenmiştir (Çizelge 5).

Dormansi çalışmalarında en etkili yöntem giberellik asitin 250 ppm uygulamasından elde edilmiştir. Giberellik asit uygulaması çimlenmeleri arttırmış fakat uygulamadaki dozların artırılması tohum çimlenmesinde negatif bir etki göstermiştir. Küçük ısırgan tohumlarında giberellik asitin düşük dozlarının çimlenmeyi daha çok arttırdığı görülmektedir (Çizelge 6).

Alkol uygulamalarının 5 ve $120 \mathrm{dk}$ uygulamaları hariç diğer uygulamaları çimlenmeyi çok az da olsa arttırmıştır (Çizelge 7). Yüksek-düşük sıcaklık uygulamalarında ise mikrodalgada 30 ve 90 s bekletmek çimlenmeleri arttırmış fakat sürelerinin daha da arttırılmasıyla (120 ve 180 s) beraber tohumların çimlenmesi azalmıştır. Yüksek sürelerde mikrodalga ışınlarına maruz kalan tohumların çimlenme potansiyelinde düşüşler meydana gelmektedir. Soğukta bekletme uygulamasında 2 gün $-86^{\circ} \mathrm{C}$ 'de bekletilen tohumlarda kısmi de olsa çimlenme de artış gözlenmiştir. Diğer soğuk uygulamalarında çimlenmede azalmalar meydana gelmiştir. Soğukta bekletme + sıcak su uygulamalarının kır teresi tohumlarına benzer olarak küçük ısırgan tohumlarında da çimlenme yönünden pozitif bir etkisi olmamıştır. Sıcak su uygulamasındaki yüksek sıcaklıkta bekletilen küçük ısırgan tohumlarının embriyosunun zarar gördüğü düşünülmektedir (Çizelge 8).

Benzer dormansi kırma yöntemlerine yönelik Bozdoğan ve ark. (2018), Rumex crispus L. (kıvırcık labada) tohumlarında sodyum hipoklorit, etanol, saf su, sülfürik asit ve hidroklorik asit, giberellik asit, mikrodalga (120 W), $-80^{\circ} \mathrm{C}$ ve $80^{\circ} \mathrm{C}$ ve $+80^{\circ} \mathrm{C}$ bir dakika bekletme uygulamalarını gerçekleştirmiştir. En iyi çimlenme sonuçlarının etanol ve sülfürik asit uygulamalarında olduğu tespit edilmiştir. Yaptığımı çalışmada ise sülfürik asit uygulamaların çimlenme oranını (120 s hariç) kontrole göre azalttığı belirlenmiştir. Çalışmamız ile Bozdoğan ve ark. (2018) yaptığı çalışma arasındaki bu farklılığın tohum kabuklarının yapısından ve kalınlığından kaynaklandığı düşünülmektedir. Küçük ısırgan tohumlarının çimlenme sürelerine $\left(T_{50}\right.$ ve $\left.T_{90}\right)$ bakıldığında çimlenen tohumların \%50'sinin çimlenme süreleri ortalama 5 ile 8 gün arasında ve $\% 90^{\prime} ı n ı n$ ise 9 
ile 12 gün arasında çimlendiği belirlenmiştir. En etkili dormansi kırma uygulaması olan giberellik asit 250 ppm'de çimlenen tohumların \%50'sinin ve \%90'ının çimlenme sürelerinin sırasıyla 4.25 ve 8.5 günde olduğu saptanmıştır.

Çizelge 5. Küçük ısırgan (Urtica urens L.) tohumlarının çimlenme oranları (\%) ve sürelerine yüksek-asit-baz uygulamalarının etkisi

Table 5. The effect of acid-base applications on the germination rates and durations of annual nettle (Urtica urens L.) seeds.

\begin{tabular}{|c|c|c|c|c|}
\hline & & Gmax (\%) & $T_{50}$ (gün) & $T_{90}$ (gün) \\
\hline Kontrol & & $35 \pm 5.41 b c$ & $6 \pm 0 \mathrm{bcd}$ & $10 \pm 1,59 a b$ \\
\hline \multirow{7}{*}{ Sülfürik asit (\%97) } & $1 \mathrm{dk}$ & $22.5 \pm 2.5 c d$ & $7 \pm 1.09 a b c$ & $11.25 \pm 0.86 \mathrm{ab}$ \\
\hline & $2 \mathrm{dk}$ & $42.5 \pm 6.3 a b$ & $7,5 \pm 0.65 a b c$ & $12.5 \pm 0.87 a$ \\
\hline & $5 \mathrm{dk}$ & $12.5 \pm 2.5 d$ & $9 \pm 3.09 a b$ & $9 \pm 3.09 a b$ \\
\hline & $15 \mathrm{dk}$ & $15 \pm 2.89 \mathrm{~cd}$ & $6.75 \pm 1.25 a b c d$ & $10.25 \pm 1.19 a b$ \\
\hline & $30 \mathrm{dk}$ & $11.25 \pm 4.27 \mathrm{~d}$ & $3.5 \pm 1.56 \mathrm{~cd}$ & $5 \pm 1.78 \mathrm{~cd}$ \\
\hline & $60 \mathrm{dk}$ & $0 \pm 0 d$ & $0 \pm 0 d$ & $0 \pm 0 d$ \\
\hline & $90 \mathrm{dk}$ & $0 \pm 0 d$ & $0 \pm 0 d$ & $0 \pm 0 d$ \\
\hline \multirow{7}{*}{ Hidroklorik asit (\%33) } & $1 \mathrm{dk}$ & $30 \pm 4,09 b c$ & $10 \pm 0.41 a$ & $11.75 \pm 0.48 \mathrm{ab}$ \\
\hline & $2 \mathrm{dk}$ & $46.25 \pm 3.15 a b$ & $6.5 \pm 1.2 \mathrm{bcd}$ & $10.75 \pm 0.48 a b$ \\
\hline & $5 \mathrm{dk}$ & $26.25 \pm 3.15 b c$ & $7 \pm 0.71 \mathrm{abc}$ & $11 \pm 0.58 \mathrm{ab}$ \\
\hline & $15 \mathrm{dk}$ & $0 \pm 0 d$ & $0 \pm 0 d$ & $0 \pm 0 d$ \\
\hline & $30 \mathrm{dk}$ & $0 \pm 0 d$ & $0 \pm 0 d$ & $0 \pm 0 d$ \\
\hline & $60 \mathrm{dk}$ & $0 \pm 0 d$ & $0 \pm 0 d$ & $0 \pm 0 d$ \\
\hline & $90 \mathrm{dk}$ & $0 \pm 0 d$ & $0 \pm 0 d$ & $0 \pm 0 d$ \\
\hline \multirow{4}{*}{ Sodyum hidroksit (\%50) } & $5 \mathrm{dk}$ & $36.25 \pm 2.4 b c$ & $7.75 \pm 1.61 \mathrm{abc}$ & $10.5 \pm 1.71 \mathrm{ab}$ \\
\hline & $10 \mathrm{dk}$ & $51.25 \pm 9.66 a b$ & $6.75 \pm 0.75 a b c d$ & $9 \pm 0.41 a b$ \\
\hline & $15 \mathrm{dk}$ & $52.5 \pm 5.96 a$ & $6.5 \pm 0.87 \mathrm{bcd}$ & $9 \pm 1.48 a b$ \\
\hline & $20 \mathrm{dk}$ & $66.25 \pm 4.27 a$ & $5 \pm 0.41 b c d$ & $7 \pm 1.36 \mathrm{bc}$ \\
\hline \multirow{4}{*}{ Sodyum hidroksit (\%40) } & $5 \mathrm{dk}$ & $43.75 \pm 6.25 a b$ & $6 \pm 0.58 \mathrm{bcd}$ & $10.5 \pm 0.65 a b$ \\
\hline & $10 \mathrm{dk}$ & $45 \pm 3.54 a b$ & $4.25 \pm 0.25 c d$ & $8.5 \pm 0.29 a b c$ \\
\hline & $15 \mathrm{dk}$ & $28.75 \pm 5.16 b c$ & $6.25 \pm 0.48 \mathrm{bcd}$ & $10.25 \pm 1.61 \mathrm{ab}$ \\
\hline & $20 \mathrm{dk}$ & $62.5 \pm 4.34 a$ & $7.25 \pm 0.95 a b c$ & $11.25 \pm 0.86 \mathrm{ab}$ \\
\hline \multirow{4}{*}{ Sodyum hidroksit (\%30) } & $5 \mathrm{dk}$ & $52.5 \pm 5.96 a$ & $4.25 \pm 0.25 c d$ & $10 \pm 1.36 \mathrm{ab}$ \\
\hline & $10 \mathrm{dk}$ & $23.75 \pm 3.75 \mathrm{~cd}$ & $6.5 \pm 0.29 b c d$ & $8.25 \pm 0.75 b c$ \\
\hline & $15 \mathrm{dk}$ & $10 \pm 2.05 d$ & $4.75 \pm 1.61 b c d$ & $4.75 \pm 1.61 \mathrm{~cd}$ \\
\hline & $20 \mathrm{dk}$ & $6.25 \pm 3.75 d$ & $3.25 \pm 2.14 \mathrm{~d}$ & $3.25 \pm 2.14 \mathrm{~d}$ \\
\hline \multirow{4}{*}{ Sodyum hidroksit (\%20) } & $5 \mathrm{dk}$ & $52.5 \pm 3.23 a$ & $5.25 \pm 0.95 b c d$ & $8.25 \pm 0.75 b c$ \\
\hline & $10 \mathrm{dk}$ & $55 \pm 3.54 a$ & $6 \pm 0.41 b c d$ & $10.75 \pm 0.48 a b$ \\
\hline & $15 \mathrm{dk}$ & $47.5 \pm 3.23 a b$ & $7.25 \pm 0.48 \mathrm{abc}$ & $11.75 \pm 1.32 \mathrm{ab}$ \\
\hline & $20 \mathrm{dk}$ & $17.5 \pm 1.45 \mathrm{~cd}$ & $8 \pm 1 \mathrm{ab}$ & $9.25 \pm 1.44 \mathrm{ab}$ \\
\hline \multirow{4}{*}{ Sodyum hipoklorit (\%15) } & $5 \mathrm{dk}$ & $37.5 \pm 5.21 b$ & $6.25 \pm 0.75 b c d$ & $11 \pm 0.71 \mathrm{ab}$ \\
\hline & $10 \mathrm{dk}$ & $38.75 \pm 4.74 a b$ & $6.5 \pm 0.87 b c d$ & $10.5 \pm 1.45 a b$ \\
\hline & $15 \mathrm{dk}$ & $46.25 \pm 7.19 a b$ & $6.5 \pm 1.05 b c d$ & $12 \pm 1.09 \mathrm{ab}$ \\
\hline & $30 \mathrm{dk}$ & $62.5 \pm 5.96 a$ & $7 \pm 1.23 a b c$ & $11 \pm 0.58 \mathrm{ab}$ \\
\hline $\mathbf{F}$ & & $24.57 * *$ & $7.5 * *$ & $12.82 * *$ \\
\hline
\end{tabular}

$\pm=$ Standart sapma değerlerini vermektedir. $+^{* *}=$ Duncan $P<0.01$ önem seviyesinde istatistiksel olarak önemlidir.

Çizelge 6. Küçük ısırgan (Urtica urens L.) tohumlarının çimlenme oranları (\%) ve sürelerine giberallik asit uygulamalarının etkisi Table 6. The effect of gibberallic acid applications on the germination rates and durations of annual nettle (Urtica urens L.) seeds.

\begin{tabular}{cccccc}
\hline & & Gmax (\%) & T50 (gün) & T90 (gün) \\
\hline & Kontrol & & $35 \pm 5.41 \mathrm{c}$ & $6 \pm 0 \mathrm{a}$ & $10 \pm 1.59 \mathrm{a}$ \\
\hline & & $250 \mathrm{ppm}$ & $85 \pm 3.54 \mathrm{a}$ & $4.25 \pm 0.25 \mathrm{~b}$ & $8.5 \pm 1.71 \mathrm{ab}$ \\
Giberellik asit & $500 \mathrm{ppm}$ & $82.5 \pm 5.96 \mathrm{a}$ & $3.75 \pm 0.25 \mathrm{~b}$ & $4.5 \pm 0.5 \mathrm{c}$ \\
& & $1000 \mathrm{ppm}$ & $58.75 \pm 5.91 \mathrm{~b}$ & $4.25 \pm 0.25 \mathrm{~b}$ & $6.75 \pm 0.48 \mathrm{abc}$ \\
& & $2000 \mathrm{ppm}$ & $56.25 \pm 6.25 \mathrm{~b}$ & $4.25 \pm 0.25 \mathrm{~b}$ & $6 \pm 0.82 \mathrm{bc}$ \\
\hline
\end{tabular}

$\pm=$ Standart sapma değerlerini vermektedir. $+{ }^{*}=$ Duncan $P<0.05$ önem seviyesinde istatistiksel olarak önemlidir. $+* *=$ Duncan 
$P<0.01$ önem seviyesinde istatistiksel olarak önemlidir.

Çizelge 7. Küçük ısırgan (Urtica urens L.) tohumlarının çimlenme oranları (\%) ve sürelerine etanol uygulamalarının etkisi

Table 7. The effect of ethanol applications on the germination rates and durations of annual nettle (Urtica urens L.) seeds.

\begin{tabular}{|c|c|c|c|c|}
\hline & & Gmax (\%) & $T_{50}$ (gün) & $T_{90}$ (gün) \\
\hline \multicolumn{2}{|c|}{ Kontrol } & $35 \pm 5.41 \mathrm{ab}$ & $6 \pm 0 b c$ & $10 \pm 1.59 a$ \\
\hline \multirow{6}{*}{ Etanol (\%96) } & $5 \mathrm{dk}$ & $28.75 \pm 3.15 b$ & $6.25 \pm 0.48 b c$ & $10.75 \pm 0.95 a$ \\
\hline & $15 \mathrm{dk}$ & $35 \pm 5 a b$ & $9.75 \pm 0.48 a$ & $11.25 \pm 0.75 a$ \\
\hline & $30 \mathrm{dk}$ & $46.25 \pm 3.15 a$ & $7 \pm 0.92 b$ & $10.25 \pm 0.48 a$ \\
\hline & $60 \mathrm{dk}$ & $47.5 \pm 6.62 a$ & $5 \pm 0.41 c$ & $9.5 \pm 1.33 a$ \\
\hline & $90 \mathrm{dk}$ & $42.5 \pm 1.45 \mathrm{ab}$ & $5.5 \pm 0.5 b c$ & $9.5 \pm 0.87 a$ \\
\hline & $120 \mathrm{dk}$ & $33.75 \pm 6.58 a b$ & $5.5 \pm 0.5 b c$ & $9.25 \pm 0.63 a$ \\
\hline \multicolumn{2}{|c|}{$\mathbf{F}$} & 2.15öd & $9.14 * *$ & 0.53öd \\
\hline
\end{tabular}

\pm = Standart sapma değerlerini vermektedir. + öd $=$ İstatiksel olarak önemli değildir. (Duncan $P>0.05)+* *=$ Duncan $P<0.01$ önem seviyesinde istatistiksel olarak önemlidir

Çizelge 8. Küçük ısırgan (Urtica urens L.) tohumlarının çimlenme oranları (\%) ve sürelerine yüksek-düşük sıcaklık uygulamalarının etkisi

Table 8. The effect of high-low temperature applications on the germination rates and durations of annual nettle (Urtica urens L.) seeds.

\begin{tabular}{|c|c|c|c|c|}
\hline & & Gmax (\%) & $T_{50}$ (gün) & T90 (gün) \\
\hline Kontrol & & $35 \pm 5.41 \mathrm{ab}$ & $6 \pm 0 b c$ & $10 \pm 1.59 a b$ \\
\hline \multirow{6}{*}{ Mikrodalga (100 watt) } & $10 \mathrm{sn}$ & $35 \pm 8.9 a b$ & $4.75 \pm 0.25 b c$ & $9.25 \pm 1.66 b$ \\
\hline & $30 \mathrm{sn}$ & $45 \pm 9.36 a$ & $7 \pm 1.16 \mathrm{ab}$ & $10 \pm 1.48 \mathrm{ab}$ \\
\hline & $60 \mathrm{sn}$ & $35 \pm 7.36 a b$ & $8.25 \pm 1.71 \mathrm{ab}$ & $12.25 \pm 0.48 \mathrm{ab}$ \\
\hline & $90 \mathrm{sn}$ & $43.75 \pm 2.4 a$ & $8 \pm 0.41 \mathrm{ab}$ & $12.75 \pm 0.75 a$ \\
\hline & $120 \mathrm{sn}$ & $26.25 \pm 6.58 \mathrm{bc}$ & $9.75 \pm 0.48 a$ & $11.5 \pm 0.5 \mathrm{ab}$ \\
\hline & $180 \mathrm{sn}$ & $3.75 \pm 3.75 d$ & $1.25 \pm 1.25 c$ & $1.25 \pm 1.25 \mathrm{~d}$ \\
\hline \multirow{4}{*}{ Soğukta bekletme } & 1 gün $-86^{\circ} \mathrm{C}$ & $22.5 \pm 4.79 b c$ & $8.75 \pm 0.48 a b$ & $11.5 \pm 1.2 \mathrm{ab}$ \\
\hline & 2 gün $-86^{\circ} \mathrm{C}$ & $46.25 \pm 4.27 a$ & $7.5 \pm 0.87 a b$ & $11.5 \pm 0.65 a b$ \\
\hline & 4 gün $-86^{\circ} \mathrm{C}$ & $22.5 \pm 6.3 b c$ & $7 \pm 1.48 \mathrm{ab}$ & $12.75 \pm 0.95 a$ \\
\hline & 7 gün $-86^{\circ} \mathrm{C}$ & $16.25 \pm 5.91 \mathrm{~cd}$ & $4.25 \pm 1.55 c$ & $5.25 \pm 1.8 c$ \\
\hline \multirow{5}{*}{ Soğukta bekletme + Sıcak su } & 0 gün $90^{\circ} \mathrm{C}$ & $1.25 \pm 1.25 \mathrm{~d}$ & $0 \pm 0 c$ & $0 \pm 0 d$ \\
\hline & 1 gün $-86 / 90^{\circ} \mathrm{C}$ & $0 \pm 0 d$ & $0 \pm 0 c$ & $0 \pm 0 d$ \\
\hline & 2 gün $-86 / 90^{\circ} \mathrm{C}$ & $0 \pm 0 d$ & $0 \pm 0 c$ & $0 \pm 0 d$ \\
\hline & 4 gün $-86 / 90^{\circ} \mathrm{C}$ & $0 \pm 0 d$ & $0 \pm 0 c$ & $0 \pm 0 d$ \\
\hline & 7 gün $-86 / 90^{\circ} \mathrm{C}$ & $0 \pm 0 \mathrm{~d}$ & $0 \pm 0 c$ & $0 \pm 0 \mathrm{~d}$ \\
\hline $\mathbf{F}$ & & $11.97 * *$ & $18.79 * *$ & $30.59 * *$ \\
\hline
\end{tabular}

$\pm=$ Standart sapma değerlerini vermektedir. $+* *=$ Duncan $P<0.01$ önem seviyesinde istatistiksel olarak önemlidir

Kara banotu tohumlarına yönelik dormansi kırma çalışmalarında sadece sodyum hidroksit $(\mathrm{NaOH})$ uygulamasının tohumların çimlenmesinde bir etkisi olduğu belirlenmiştir. Diğer uygulamalarda ise tohumlarda herhangi bir çimlenme elde edilmemiştir. Sodyum hidroksitin \%30'luk konsantrasyonunda $20 \mathrm{dk}$ bekletilen kara banotu tohumlarının \%100 çimlenmesi ile birlikte en güçlü dormansi kırma yönteminin bu uygulama olduğu saptanmıştır (Çizelge 9). Tohumlarda dormansi kırma uygulamalarında \%40'lık $\mathrm{NaOH}^{\prime}$ da 20 dk ve \%20'lik $\mathrm{NaOH}^{\prime}$ da 15 ile $20 \mathrm{dk}$ uygulamaları çimlenmeyi arttırmada diğer etkili uygulamalar olarak belirlenmiştir. Çırak ve ark. (2004), kara banotu tohumlarının çimlenme biyolojisi üzerine yaptığı çalışmada tohumlarda bulunan dormansiyi ortadan kaldırmak için sıcak su $\left(40,50\right.$ ve $\left.60^{\circ} \mathrm{C}\right)$, giberellik asit $(5$, 10 ve $\left.15 \mathrm{mg} \mathrm{L}^{-1}\right)$, sülfürik asit $(\% 1,2$ ve 3$)$ ve sülfürik asit+giberellik (\%1 $\mathrm{H}_{2} \mathrm{SO}_{4}$ ve $15 \mathrm{mg} \mathrm{L}^{-1} \mathrm{GA}$ ) asit uygulamalarını denemişlerdir. Yapılan bu çalışmanın kontrolünde da çimlenme oranı \%0 (aydınlık) ve \%2 (karanlık) olarak belirlenmiş ve bu sonuçlar çalışmamıza benzerlik göstermektedir. Tohumdaki dormansi uygulamaları sonucunda en iyi çimlenme oranları sülfürik asit+giberellik asit karanlık (\%68) ve aydınlık 
(\%60) ortam olarak belirlenmiştir. Giberellik asitin yalnız başına tohumların çimlenmesi üzerinde büyük bir etkisi olmamıştır. Sülfürik asit uygulamasında en iyi sonuç ise \%1'lik $\mathrm{H}_{2} \mathrm{SO}_{4}$ karanlık ortamda (\%45) gözlenmiştir. Çırak ve ark. (2004), yaptığı çalışmada \%1'lik sülfürik asit kullanımı sonucunda \%45 oranında çimlenmeye ulaşması ve çalışmamızdaki \%97'lik sülfürik asitte bekletmenin çimlenme üzerine herhangi bir etkisinin olmaması $H$. niger'e yüksek konsantrasyonlu sülfürik asit uygulamalarının tohum embriyosuna zarar verdiğini kanıtlamaktadır. Başka bir çalışmada Al Taweel ve ark. (2018), Hyoscyamus niger tohumlarına elektrik şoku uygulayarak çimlenmesini arttırmayı amaçlamıştır. Kontroldeki (OA) çimlenme oranı \%52.12 olan kara banotunun 2, 4 ve $6 \mathrm{~A}$ uygulamaları sonunda çimlenme oranları sırasıyla \%68.05, \%79.13 ve \%66.10 olarak belirlenmiştir.

Çizelge 9. Kara banotu (Hyoscyamus niger L.) tohumlarının çimlenme oranları (\%) ve sürelerine yüksek-asit-baz uygulamalarının etkisi

Table 9. The effect of acid-base applications on the germination rates and durations of black henbane (Hyoscyamus niger L.) seeds.

\begin{tabular}{|c|c|c|c|c|}
\hline & & Gmax (\%) & $T_{50}$ (gün) & T90 (gün) \\
\hline Kontrol & & $0 \pm 0 c$ & $0 \pm 0 c$ & $0 \pm 0 c$ \\
\hline \multirow{4}{*}{ Sodyum hidroksit (\%50) } & $5 \mathrm{dk}$ & $0 \pm 0 c$ & $0 \pm 0 c$ & $0 \pm 0 c$ \\
\hline & $10 \mathrm{dk}$ & $0 \pm 0 c$ & $0 \pm 0 c$ & $0 \pm 0 c$ \\
\hline & $15 \mathrm{dk}$ & $1.25 \pm 1.25 c$ & $0 \pm 0 c$ & $0 \pm 0 c$ \\
\hline & $20 \mathrm{dk}$ & $1.25 \pm 1.25 c$ & $0 \pm 0 c$ & $0 \pm 0 c$ \\
\hline \multirow{4}{*}{ Sodyum hidroksit (\%40) } & $5 \mathrm{dk}$ & $0 \pm 0 c$ & $0 \pm 0 c$ & $0 \pm 0 c$ \\
\hline & $10 \mathrm{dk}$ & $0 \pm 0 c$ & $0 \pm 0 c$ & $0 \pm 0 c$ \\
\hline & $15 \mathrm{dk}$ & $3.75 \pm 1.25 c$ & $0 \pm 0 c$ & $0 \pm 0 c$ \\
\hline & $20 \mathrm{dk}$ & $32.5 \pm 3.23 b$ & $1 \pm 0 \mathrm{a}$ & $1.25 \pm 0.25 b$ \\
\hline \multirow{4}{*}{ Sodyum hidroksit (\%30) } & $5 \mathrm{dk}$ & $0 \pm 0 c$ & $0 \pm 0 c$ & $0 \pm 0 c$ \\
\hline & $10 \mathrm{dk}$ & $0 \pm 0 c$ & $0 \pm 0 c$ & $0 \pm 0 c$ \\
\hline & $15 \mathrm{dk}$ & $1.25 \pm 1.25 c$ & $0 \pm 0 c$ & $0 \pm 0 c$ \\
\hline & $20 \mathrm{dk}$ & $100 \pm 0 a$ & $1 \pm 0 a$ & $1 \pm 0 \mathrm{bc}$ \\
\hline \multirow{4}{*}{ Sodyum hidroksit (\%20) } & $5 \mathrm{dk}$ & $3.75 \pm 3.75 c$ & $0.5 \pm 0.5 b$ & $0.5 \pm 0.5 b c$ \\
\hline & $10 \mathrm{dk}$ & $8.75 \pm 3.15 c$ & $0.75 \pm 0.25 a b$ & $0.75 \pm 0.25 b c$ \\
\hline & $15 \mathrm{dk}$ & $40 \pm 5.78 b$ & $1 \pm 0 a$ & $2.25 \pm 1.25 \mathrm{a}$ \\
\hline & $20 \mathrm{dk}$ & $85 \pm 5 a$ & $1 \pm 0 \mathrm{a}$ & $1 \pm 0 b c$ \\
\hline $\mathbf{F}$ & & 166.01** & $10.85^{* *}$ & $371 * *$ \\
\hline
\end{tabular}

$\pm=$ Standart sapma değerlerini vermektedir. $+* *=$ Duncan $P<0.01$ önem seviyesinde istatistiksel olarak önemlidir

\section{Çimlenme Sıcaklığı Çalışmaları}

Kır teresi, küçük ısırgan ve kara banotu tohumlarının çimlenme sıcaklığı çalışmalarında 5'er derece arttırılarak $5-45^{\circ} \mathrm{C}$ sıcaklık aralıkları çalışımıştır. Çimlenme sıcaklığı çalışmaları kır teresi, küçük ısırgan ve kara banotu tohumlarına sırasıyla giberellik asit 500 ile 2000 ppm, giberellik asit $250 \mathrm{ppm}$ ve $\% 30$ sodyum hidroksit $20 \mathrm{dk}$ olan en uygun dormansi yöntemi belirlendikten sonra kurulmuştur. Çalışmada çimlenme sayımları her gün yapılarak çimlenme oranları (\%) ve süreleri (gün) tespit edilmiştir.

Kır teresi tohumlarına yönelik çimlenme sıcaklığı çalışmasında 5 ve $45^{\circ} \mathrm{C}$ sıcaklıklarda çimlenmenin olmadığı, en uygun çimlenmenin ise $15-25^{\circ} \mathrm{C}$ arası sıcaklıklarda olduğu belirlenmiştir (Çizelge 10 ve Şekil
1). Yapılan çalışmada 5 ve $45^{\circ} C^{\prime}$ nin tohum canlılık aktivitesini durduğu görülmektedir. Çimlenmenin oranının en yüksek (\%90) olduğu çimlenme sıcaklığı ise $20^{\circ} \mathrm{C}$ olarak belirlenmiştir. Hosseini ve ark. (2017), 5$35^{\circ} \mathrm{C}$ sıcaklıkları arasında yaptığı çalışmada kır teresinin çimlenme sıcaklığını en uygun $15^{\circ} \mathrm{C}$ ve $30^{\circ} \mathrm{C}$ sıcaklıklarda belirlemiştir. Çalışmamızda da en uygun sıcaklık aralığı Hosseini ve ark. (2017)'nin çalışması ile benzerlik göstermektedir. Sıcaklığın $15^{\circ} \mathrm{C}^{\prime}$ nin altına düştüğü ve $30^{\circ} \mathrm{C}^{\prime}$ nin üzerine çıktığı durumlarda çimlenmelerin azaldığı belirlenmiştir. Kır teresinin sıcaklık çalışmasındaki çimlenme sürelerine $\left(T_{50}\right.$ ve $\left.T_{90}\right)$ bakıldığında tohumların minimum 3 maksimum 12 günde çimlendiği tespit edilmiştir. 
Çizelge 10. Kır teresi (Cardaria draba (L.) Desv.)'nin farklı sıcaklık derecelerindeki çimlenme oranları ve süreleri (gün) Table 10. Germination rates and durations of whitetop (Cardaria draba (L.) Desv.) at different temperatures.

\begin{tabular}{cccc}
\hline Sıcaklık ( $\left.{ }^{\circ} \mathrm{C}\right)$ & Gmax (\%) & $T_{50}$ (gün) & $T_{90}$ (gün) \\
\hline $5^{\circ} \mathrm{C}$ & $0 \pm 0 \mathrm{c}$ & $0 \pm 0 \mathrm{~d}$ & $0 \pm 0 \mathrm{~d}$ \\
$10^{\circ} \mathrm{C}$ & $45 \pm 2.89 \mathrm{~b}$ & $8.75 \pm 0.48 \mathrm{a}$ & $11.5 \pm 1.2 \mathrm{a}$ \\
$15^{\circ} \mathrm{C}$ & $87.5 \pm 6.3 \mathrm{a}$ & $6.25 \pm 0.25 \mathrm{~b}$ & $7 \pm 0.41 \mathrm{~b}$ \\
$20^{\circ} \mathrm{C}$ & $90 \pm 4.09 \mathrm{a}$ & $5.5 \pm 0.65 \mathrm{~b}$ & $8.25 \pm 0.63 \mathrm{~b}$ \\
$25^{\circ} \mathrm{C}$ & $82.5 \pm 17.5 \mathrm{a}$ & $5.5 \pm 1.2 \mathrm{~b}$ & $7.25 \pm 1.25 \mathrm{~b}$ \\
$30^{\circ} \mathrm{C}$ & $77.5 \pm 4.79 \mathrm{a}$ & $5.25 \pm 0.48 \mathrm{~b}$ & $7 \pm 0 \mathrm{~b}$ \\
$35^{\circ} \mathrm{C}$ & $12.5 \pm 9.47 \mathrm{c}$ & $2.5 \pm 1.45 \mathrm{c}$ & $2.75 \pm 1.61 \mathrm{c}$ \\
$40^{\circ} \mathrm{C}$ & $0 \pm 0 \mathrm{c}$ & $0 \pm 0 \mathrm{~d}$ & $0 \pm 0 \mathrm{~d}$ \\
$45^{\circ} \mathrm{C}$ & $0 \pm 0 \mathrm{c}$ & $0 \pm 0 \mathrm{~d}$ & $0 \pm 0 \mathrm{~d}$ \\
\hline $\mathbf{F}$ & $\mathbf{2 6 . 6 * *}$ & $\mathbf{1 7 . 4 * *}$ & $\mathbf{2 2 . 3 2 * *}$ \\
\hline
\end{tabular}

$\pm=$ Standart sapma değerlerini vermektedir. $+* *=$ Duncan $P<0.01$ önem seviyesinde istatistiksel olarak önemlidir

Küçük ısırgan tohumlarına yönelik çimlenme sıcaklığı çalışmasında da yine 5 ve $45^{\circ} \mathrm{C}$ sıcaklıklarda çimlenmenin olmadığı, en uygun çimlenmenin ise 20$30^{\circ} \mathrm{C}$ arası sıcaklıklarda olduğu belirlenmiştir (Çizelge ve Şekil 1). Coleman ve ark. (2018), küçük ısırgan otu (Urtica urens) tohumlarının en uygun çimlenme sıcaklığının $20-25^{\circ} \mathrm{C}$ arasında olduğunu belirlemişlerdir. Coleman ve ark. (2018) ile yaptığımız çalışma arasındaki bu küçük farkın yabancı ot tohumlarının yetiştiği yerdeki ekolojik şartlar ve tohumların toplanma zamanından kaynaklanmış düşünülmektedir. Yapılan çalışmada 5 ve $45^{\circ} \mathrm{C}^{\prime}$ nin tohum canlılık aktivitesini durduğu görülmektedir. Çimlenmenin oranının en yüksek (\%82.5) olduğu çimlenme sıcaklığı ise $25^{\circ} \mathrm{C}$ olarak saptanmıştır. Sıcaklığın $15^{\circ} \mathrm{C}^{\prime}$ nin altına düştüğü ve $30^{\circ} \mathrm{C}$ 'nin üzerine çıktığı durumlarda çimlenmelerin azaldığı belirlenmiştir. Çalışmamıza benzer şekilde Andersen (1968) $U$. urens tohumlarında çimlenmenin optimum $25^{\circ} \mathrm{C}^{\prime}$ de olduğunu ve sıcaklık $20^{\circ} \mathrm{C}$ 'nin altına düştükçe çimlenmenin azaldığını belirlemiştir. $U$. urens'in sıcaklık çalışmasındaki çimlenme sürelerine $\left(T_{50}\right.$ ve $T_{90}$ ) bakıldığında çimlenen tohumların minimum 4 maksimum 11 günde çimlendiği tespit edilmiştir.

Çizelge 11. Küçük ısırgan (Urtica urens L.)'ın farklı sıcaklık derecelerindeki çimlenme oranları ve süreleri

Table 11. Germination rates and durations of annual nettle (Urtica urens L.) at different temperatures.

\begin{tabular}{cccc}
\hline Sıcaklık $\left({ }^{\circ} \mathrm{C}\right)$ & Gmax (\%) & $T_{50}$ (gün) & T90 (gün) \\
\hline $5^{\circ} \mathrm{C}$ & $0 \pm 0 \mathrm{c}$ & $0 \pm 0 \mathrm{~d}$ & $0 \pm 0 \mathrm{~d}$ \\
$10^{\circ} \mathrm{C}$ & $30 \pm 14.15 \mathrm{~b}$ & $10.75 \pm 0.75 \mathrm{a}$ & $10.75 \pm 0.75 \mathrm{a}$ \\
$15^{\circ} \mathrm{C}$ & $62.5 \pm 7.5 \mathrm{a}$ & $7 \pm 0.71 \mathrm{~b}$ & $8.5 \pm 0.87 \mathrm{~b}$ \\
$20^{\circ} \mathrm{C}$ & $70 \pm 10.81 \mathrm{a}$ & $4 \pm 0 \mathrm{c}$ & $6 \pm 0.71 \mathrm{c}$ \\
$25^{\circ} \mathrm{C}$ & $82.5 \pm 11.09 \mathrm{a}$ & $4 \pm 0.41 \mathrm{c}$ & $5 \pm 0 \mathrm{c}$ \\
$30^{\circ} \mathrm{C}$ & $80 \pm 9.13 \mathrm{a}$ & $4.25 \pm 0.25 \mathrm{c}$ & $5.25 \pm 0.25 \mathrm{c}$ \\
$35^{\circ} \mathrm{C}$ & $22.5 \pm 2.5 \mathrm{bc}$ & $6 \pm 0 \mathrm{~b}$ & $6 \pm 0 \mathrm{c}$ \\
$40^{\circ} \mathrm{C}$ & $0 \pm 0 \mathrm{c}$ & $0 \pm 0 \mathrm{~d}$ & $0 \pm 0 \mathrm{~d}$ \\
$45^{\circ} \mathrm{C}$ & $0 \pm 0 \mathrm{c}$ & $0 \pm 0 \mathrm{~d}$ & $0 \pm 0 \mathrm{~d}$ \\
\hline $\mathbf{F}$ & $\mathbf{1 6 . 2 6 * *}$ & $\mathbf{7 8 . 4 2 * *}$ & $59.19^{* *}$ \\
\hline
\end{tabular}

$\pm=$ Standart sapma değerlerini vermektedir. $+^{* *}=$ Duncan $P<0.01$ önem seviyesinde istatistiksel olarak önemlidir

Kara banotu tohumlarına yönelik çimlenme sıcaklığı çalışmasında $5-45^{\circ} \mathrm{C}$ sıcaklıkta çimlenmenin olmadığı, en uygun çimlenmenin $(\% 100)$ ise $20^{\circ} \mathrm{C}$ olduğu belirlenmiştir (Çizelge 12 ve Şekil 1). Yapılan çalışmada 5 ve $45^{\circ} \mathrm{C}^{\prime}$ nin tohum canlılık aktivitesini durduğu görülmektedir. Sıcaklığın $20^{\circ} \mathrm{C}^{\prime}$ nin altına düştüğü ve üstüne çıktığı durumlarda çimlenmelerin azaldığı belirlenmiştir. Kara banotunun sıcaklık çalışmasındaki çimlenme sürelerine ( $T_{50}$ ve $T_{90}$ ) bakıldığında çimlenen tohumların minimum 1 maksimum 5 günde çimlendiği tespit edilmiştir.

\section{Sonuç ve Öneriler}

Yapılan çalışmalar sonucunda kır teresi, küçük ısırgan ve kara banotu ile yapılan çalışma sayısı oldukça sınırlıdır. $\mathrm{Bu}$ bitkilerin çimlenme biyolojilerinin iyi bilinmesi bu bitkilere karşı mücadele yöntemlerinin geliştirilmesi 
açısından önemli olmaktadır. Yapılan laboratuvar çalışmaları sonucunda bu bitkilerin tohumlarında en etkili dormansi kırma uygulamaları, sırasıyla; giberellik asitin 500 ile 2000 ppm, giberellik asitin 250 ppm ve \%30'luk sodyum hidroksit uygulamasında $20 \mathrm{dk}$ bekletilmesi olarak belirlenmiştir. Kır teresi, küçük ısırgan ve kara banotu tohumlarındaki en uygun çimlenme sıcaklıkları ise sırasıyla 20,25 ve $20^{\circ} \mathrm{C}$ olarak belirlenmiştir. Yapılan dormansi çalışmalarında en uygun çimlenme süreleri ( $T_{50}$ ve $T_{90}$ ) ise minimum ve maksimum olarak sırasıyla kır teresi için 3 ile 10 gün, küçük ısırgan için 5 ile 12 gün ve kara banotu için ise 1 ile 5 gün arasında olduğu hesaplanmıştır.

Çizelge 12. Kara banotu (Hyoscyamus niger L.)'nun farklı sıcaklık derecelerindeki çimlenme oranları ve süreleri Table 12. Germination rates and durations of black henbane (Hyoscyamus niger L.) at different temperatures.

\begin{tabular}{|c|c|c|c|}
\hline Sıcaklık ( $\left.{ }^{\circ} \mathrm{C}\right)$ & Gmax (\%) & $T_{50}$ (gün) & $T_{90}$ (gün) \\
\hline $5^{\circ} \mathrm{C}$ & $0 \pm 0 d$ & $0 \pm 0 b$ & $0 \pm 0 b$ \\
\hline $10^{\circ} \mathrm{C}$ & $25 \pm 5 c$ & $1 \pm 0 \mathrm{a}$ & $2.75 \pm 1.75 a b$ \\
\hline $15^{\circ} \mathrm{C}$ & $25 \pm 8.67 c$ & $0.75 \pm 0.25 a$ & $4.25 \pm 2.5 a$ \\
\hline $20^{\circ} \mathrm{C}$ & $100 \pm 0 a$ & $1 \pm 0 a$ & $1 \pm 0 a b$ \\
\hline $25^{\circ} \mathrm{C}$ & $77.5 \pm 6.3 b$ & $1 \pm 0 \mathrm{a}$ & $1 \pm 0 a b$ \\
\hline $30^{\circ} \mathrm{C}$ & $72.5 \pm 7.5 b$ & $1 \pm 0 \mathrm{a}$ & $1 \pm 0 a b$ \\
\hline $35^{\circ} \mathrm{C}$ & $67.5 \pm 2.5 b$ & $1 \pm 0 \mathrm{a}$ & $1.25 \pm 0.25 a b$ \\
\hline $40^{\circ} \mathrm{C}$ & $62.5 \pm 2.5 b$ & $1 \pm 0 \mathrm{a}$ & $1.75 \pm 0.25 a b$ \\
\hline $45^{\circ} \mathrm{C}$ & $0 \pm 0 \mathrm{~d}$ & $0 \pm 0 \mathrm{~b}$ & $0 \pm 0 \mathrm{~b}$ \\
\hline $\mathbf{F}$ & $43.14 * *$ & $15.86 * *$ & 1.48öd \\
\hline
\end{tabular}

\pm = Standart sapma değerlerini vermektedir. + öd $=$ İstatiksel olarak önemli değildir. (Duncan $P>0.05)+* *=$ Duncan $P<0.01$ önem seviyesinde istatistiksel olarak önemlidir

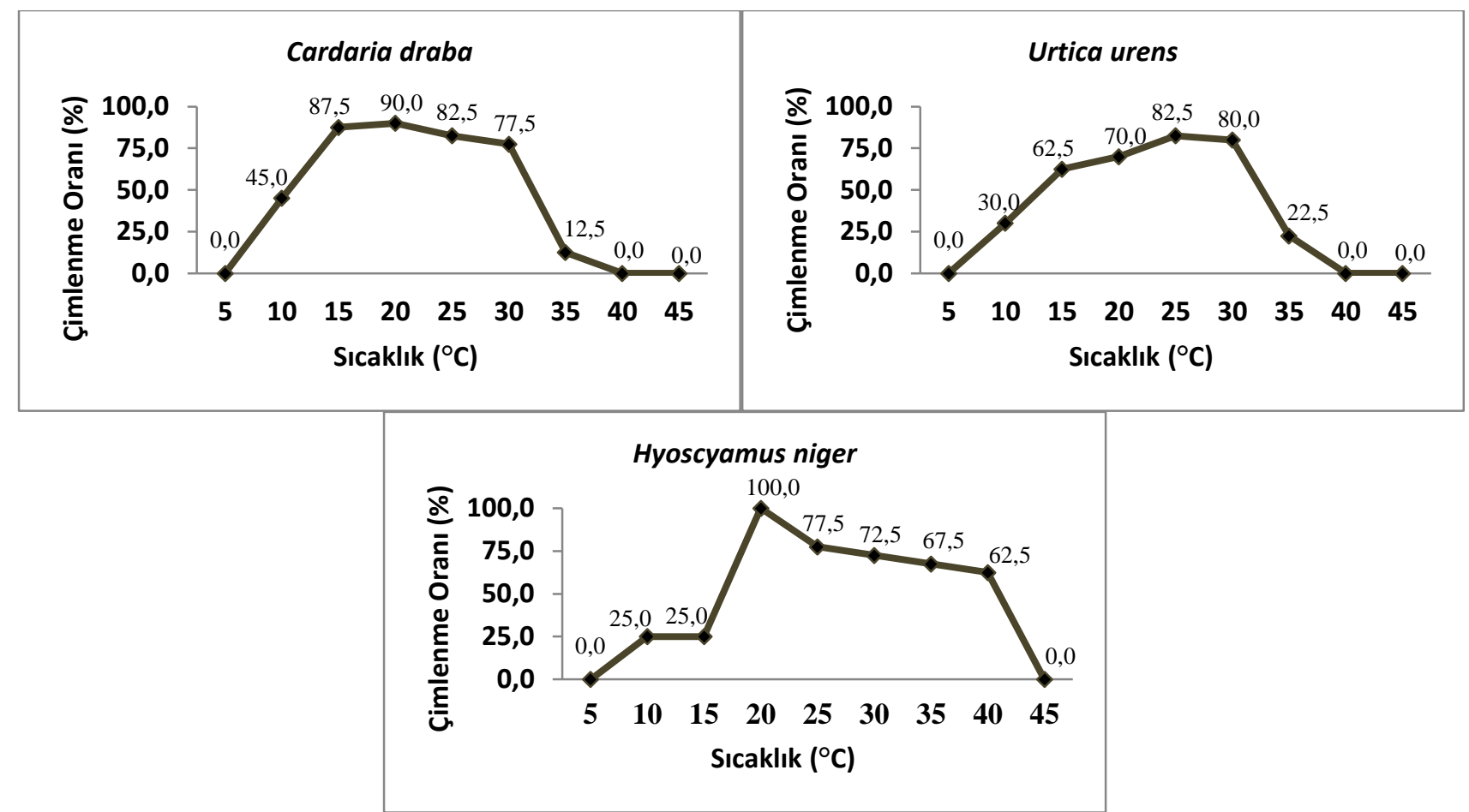

Şekil 1. Kır teresi (Cardaria draba (L.) Desv.), küçük ısırgan (Urtica urens L.) ve kara banotu (Hyoscyamus niger L.) tohumlarının çimlenme sıcaklıkları

Figure 1. Germination temperature of whitetop (Cardaria draba (L.) Desv.), annual nettle (Urtica urens L.) and black henbane (Hyoscyamus niger L.) seeds.

Sonuç olarak kır teresi, küçük ısırgan ve kara banotu yabancı ot tohumlarına yapılan dormansi kırma ve çimlenme sıcaklığı çalışmalarında tohumların en uygun çimlenme oranı ve süresi belirlenmiştir. Bu çalışma ile birlikte bu yabancı otların tarım içi ve dışı alanlarındaki zararlarına yönelik ve alternatif tıp gibi yararına yönelik 
çalışmalarda araştırıcılara bir alt yapı sağlayacağı ve uygun çimlenme oranlarının ve sürelerinin bilinmesi ile çalışmalarda ön bilgi verilmesi açsından önemli olacağı beklenmektedir.

\section{ÖZET}

Amaç: Bu çalışmanın amacı, bazı yabancı ot (kır teresi (Cardaria draba (L.) Desv.), küçük ısırgan (Urtica urens L.) ve kara banotu (Hyoscyamus niger L.)) tohumlarında en uygun dormansi kırma yönteminin ve en uygun çimlenme sıcaklığının belirlenmesidir.

Yöntem ve Bulgular: Değişik dormansi kırma yöntemleri uygulanarak (asit-baz (sülfürik asit $(1,2,15,30,60$ ve 90 $\mathrm{dk})$, hidroklorik asit $(5,15,30$ ve $60 \mathrm{dk})$, sodyum hidroksit (\%50, \%40, \%30 ve \%20 konsantrasyonlarda 5, $10,15$ ve $20 \mathrm{dk})$ ve sodyum hipoklorit $(5,10,15$ ve 30 dk)), hormon (giberellik asit (250, 500, 750 ve 1000 ppm)), alkol (etanol $(5,15,30,60,90$ ve $120 \mathrm{dk}))$ ve yüksek-düşük sıcaklık (mikrodalga $(10,30,45,90$ ve 180 sn), ve soğukta bekletme (0 gün kontrol, 1 gün $-86^{\circ} \mathrm{C}, 2$ gün $-86^{\circ} \mathrm{C}, 4$ gün $-86^{\circ} \mathrm{C}$ ve 7 gün $-8^{\circ} \mathrm{C}$ ) ve soğukta bekletme + sıcak su $\left(0\right.$ gün $90^{\circ} \mathrm{C}$, 1 gün $-86 / 90^{\circ} \mathrm{C}$, 2 gün $86 / 90^{\circ} \mathrm{C}$, 4 gün $-86 / 90^{\circ} \mathrm{C}$ ve 7 gün $-86 / 90^{\circ} \mathrm{C}$ )) uygulamaları yapılmıştır. Kır teresi, küçük ısırgan ve kara banotu yabancı otlarının en uygun çimlenme özellikleri ortaya konulmuş daha sonra bu yabancı otların tohumlarında en uygun dormansi kırma yöntemi ve çimlenme sıcaklıkları belirlenmiştir.

Genel Yorum: Elde edilen sonuçlara göre en uygun dormansi kırma yöntemi olarak: kır teresi için giberellik asitin 500 ile 2000 ppm dozları, küçük ısırgan için 250 ppm giberellik asit belirlenirken, kara banotu tohumlarında ise \%30 sodyum hidroksit içerisinde $20 \mathrm{dk}$ tohumların bekletilmesidir. Yabancı otların en uygun çimlenme oranları ise, kır teresi ve kara banotunda $20^{\circ} \mathrm{C}$, küçük ısırganda ise $25^{\circ} \mathrm{C}$ olarak bulunmuştur.

Çalışmanın Önemi ve Etkisi: Elde edilen sonuçların bu yabancı otların tarım içi ve dışı alanlarındaki çalışmalara bir alt yapı sağlayacağı beklenmektedir.

Anahtar Kelimeler: Kır teresi (Cardaria draba (L.) Desv.), küçük Isırgan (Urtica urens L.) kara banotu (Hyoscyamus niger L.), dormansi kırma, çimlenme sıcaklı̆̆ı.

\section{ÇIKAR ÇATIŞMA BEYANI}

Yazarlar çalışma konusunda çıkar çatışmasının olmadığını beyan eder.

\section{ARAŞTIRMACILARIN KATKI ORANI BEYANI}

Yazarlar çalışmaya eşit oranda katkı sağlamış olduklarını beyan eder.

\section{KAYNAKLAR}

Al Taweel SK, Cheyed SH, Al Amrani HA (2018) Effect of electric shock on germination and seedling growth in henbane species. Acad. J. Med. Plants 6(5): 071-078.

Andersen RN (1968) Germination and establishment of weeds for experimental purposes. Urbana, USA: Weed Sci. Soc. of America.

Anonim

https://www.tarimdanhaber.com/tarim-ve-ziraatbilgi-bankasi/tarla-bitkilerinde-yabanci-ot-hastalikve-zararlilarla-mucadele-h3264.html. (Erişim tarihi: 1 Nisan 2020)

Anonim

http://webcache.googleusercontent.com/search?q= cache:HKVOxudl8yQJ: www.wildflowers-andweeds.com/weedsinfo/

Cardaria $\mathrm{spp} . \mathrm{htm}+\& \mathrm{~cd}=1 \& \mathrm{hl}=\mathrm{tr} \& \mathrm{ct}=\quad$ lnk\&gl=tr. (Erişim tarihi: 11 Aralık 2019).

Ateş E (2017) Batman ve Şanlıurfa buğday alanlarında bulunan yabancı otlar ile yabani hardal (Sinapis arvensis L.) ve kısır yabani yulaf (Avena sterilis L.)'In bazı biyolojik özelliklerinin belirlenmesi. Yüksek Lisans Tezi, MKÜ, Fen Bil. Ens., Bitki Koruma ABD, Hatay. $148 \mathrm{~s}$.

Baes PO, Marta LV, Silvia S (2002) Germination in Prosopis ferox seeds: effects of mechanical, chemical and biological scarificators.) Arid Environ. 1 : 185189.

Bellue MK (1946) Weed seed handbook. Series VI. Calif. Dep. Agr. Bull. 22: 288.

Bozdoğan O, Karaman Y, Uyar F, Evli S, Akkaya F, Tursun N (2018) Rumex crispus L. (KIvırcık labada) tohumlarındaki dormansinin kırılmasında farklı uygulama yöntemlerinin etkileri. J. Agri. Fac. Mustafa Kemal Uni. 23(2): 188-196.

Bozdoğan O, Uyar F, Karaman Y, Demirtaş Ç, Uçar K, Tursun N (2019). Myagrum perfoliatum L. (Gönül Hardalı) tohumlarında dormansi kırma üzerine araştırmalar. Turk J. Weed Sci. 22(1):2019: 45-52. CABI

https://webcache.googleusercontent.com/search?q =cache: iou2SqFArTUJ: https://www.cabi.org/isc/datasheet/28251+\&cd=6\& hl=tr\&ct=clnk\&gl=tr. (Erişim tarihi: 9 Aralık 2019. 
Coleman M, Kristiansen P, Sindel B, Fyfe C (2018) Dwarf Nettle (Urtica urens): Weed management guide for Australian vegetable production. School of Environmental and Rural Science, University of New England, Armidale.

Çırak C, Kevseroğlu K, Sağlam B (2004) Physical and physiological dormancy in black henbane (Hyoscyamus niger L.) seeds. J. Plant Bio. 47(4) : 391395.

Gürsoy OV (1982) Yabancı Ot Kontrolünün Temel Esasları ve Şekerpancarı Tarımındaki Tatbikatı. Türkiye Şeker Fabrikaları Anonim Şirketi, Ankara.

Güncan A (2016) Yabancı Otlar ve Mücadele Prensipleri. SÜ, Zir. Fak. Konya. $311 \mathrm{~s}$.

Hartmann K, Krobb C, Mollwo A (1997) Phytochromemediated photocontrol of the germination of the Scentless Mayweed, Matricaria inodora L., and its sensitization by nitrate and temperature. J. Photochem. Photobiol. B: Biology 40: 240-252.

Hermansen A, Brodal G, Balvoll G (1999) Hot water treatments of carrot seeds: effects on seed-borne fungi, germination, emergence and yield. Seed Sci. Tech. 27: 599-613.

Hilhorst HWM, Karssen CM (1992) Seed dormancy and germination: the role of abscisic acid and gibberellins and the importance of hormone mutants. Plant Growth Reg. 11: 225-238.

Holm L, Doll J, Holm E, Pancho J, Herberger J (1997) World Weeds. Natural Histories and Distribution. New York, USA: John Wiley and Sons, Inc.

Horowitz M, Taylarson RB (1985) Behaviour of hard and permeable seeds of Abutilon theophrasti Medic. (velvetleaf). Weed Res. 25(5): 363-372.

Hosseini M, Mojab M, Zamani GR (2017) Cardinal temperatures for seed germination of wild barley, barley grass and hoary cress. Archives of Agron. Soil Sci. 63(3): 352-361.

Iglesias RG, Babiano MJ (1997) Endogenous abscisic acid during the germination of chickpea seed. Physiol. Plant 100: 500-504.

Kaya H, Üremiş i (2020) Hatay ili soğan tarlalarında bulunan yabancı otların yaygınlık ve yoğunluklarının belirlenmesi. MKÜ Tarım Bilimleri Dergisi, 24 (1): 2130.

Keller M, Kollmann J (1999) Effects of seed provenance on germination of herbs for agriculturel compensation sites. Agric. Ecosys. Environ. 72: 8799.
Kevseroğlu K (1993) Doğal floradan toplanan datura tohumlarının çimlenmesine bazı fiziksel ve kimyasal işlemlerin etkisi. Turk J. Agric. For. 17 (1993) 727735.

Majd R, Aghaie P, Monfared EK, Alebrahim MT (2013) Evaluating of some treatments on breaking seed dormancy in Mesquite. Int. J. Agro. Plant Production, 4(7): 1433-1439.

Obalı A (2009) Adi soda otu (Salsola kali subsp. ruthenica (Iljin) Soo.) tohumlarının çimlenme biyolojisi üzerinde araştırmalar. Yüksek Lisans Tezi, SÜ, Fen Bil. Ens., Bitki Koruma ABD, Konya. $42 \mathrm{~s}$.

Özer Z, Kadıoğlu I, Önen H, Tursun N (1998) Herboloji (Yabancı Ot Bilimi), Genişletilmiş 2. Baskı. Gaziosmanpaşa Üniversitesi, Ziraat Fakültesi Yayınları No:20, Kitaplar Serisi No: 10, Tokat. $403 \mathrm{~s}$.

Özer Z, Önen H, Tursun N, Uygur N (1999) Türkiye'nin bazı önemli yabancı otları (Tanımları ve Kimyasal Savaşımları). 1998. Gaziosmanpaşa Üniversitesi Ziraat Fakültesi Yayınları No: 38, Kitap Serisi No: 16.

Radosevich S, Holt J, Ghersa C (1997) Weed Ecology Implications for Management, Wiley, New York.

Solak H (2007) Konya yöresinde yaygın bazı yabancı ot tohumlarının çimlenme özellikleri üzerine araştırmalar. Yüksek Lisans Tezi, SÜ, Fen Bil. Ens., Bitki Koruma ABD, Konya. $108 \mathrm{~s}$.

Tiryaki I, Topu M (2014) A novel method to overcome coat-imposed seed dormancy in Lupinus albus L. and Trifolium pratense L.. J. Botany, 1: 6-6.

Tomer R, Maguire JD (1989) Hard seed studies in alfalfa. Seed Res. 1(7): 29-31.

Üremiş I, Soylu S, Kurt Ş, Soylu E.M, Sertkaya E (2020) Hatay ili havuç ekim alanlarında bulunan yabancı ot türleri, yaygınlıkları, yoğunlukları ve durumlarının değerlendirilmesi. Tekirdağ Namık Kemal Üniversitesi Ziraat Fakültesi Dergisi, 17 (2): 211-228.

Yazlık A, Üremiş i (2020) Kanyaşın [Sorghum halepense L. (Pers.)] bazı güçlü bitki türleri ile etkileşimi. MKÜ Tarım Bilimleri Dergisi, 24 (2): 110-115. 